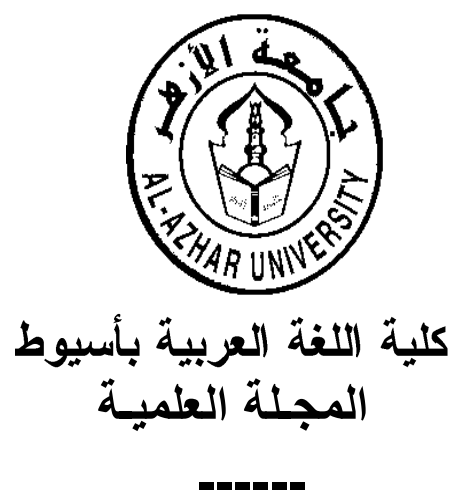

\title{
الروية السردية
}

في

رواية أنا يوسف للكاتب أيمن العتوم

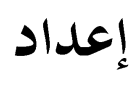

د/ نقيسة محمد عبد الفّاح

$$
\text { مدرس الأدب والنقد }
$$

بكلية الاراسات الإسلامية والعربية للبنات بالقاهرة

( العدد التاسع والثلاثون )

( الإصدار الثاني ـ الجزء السادس )

$$
\left.\left(b^{r} \cdot r \cdot / \Delta\right) \leq \varepsilon\right)
$$




\section{الروية السردية في رواية أنا يوسف للكاتب أيمن العتوم}

\section{الروية السردية في رواية أنا يوسف

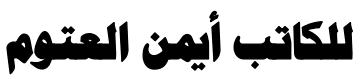

نفيسة محمد عبد الفتاح قسم الأدب والنقد - كلية الار اسات الإسلامية والعربية للبنات - بالقاهرة. البريد الإكتروني:zaitonah8@azhar.edu.eg

الروئة السردية مصطلح نقدي عرف طريقه إلى الاراسات الأدبية المتعلقة بالسرد

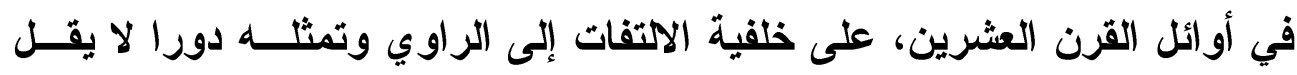

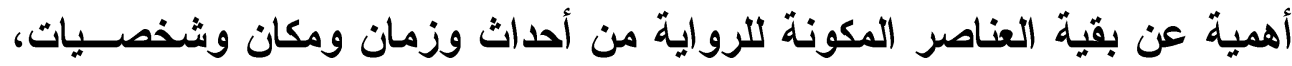

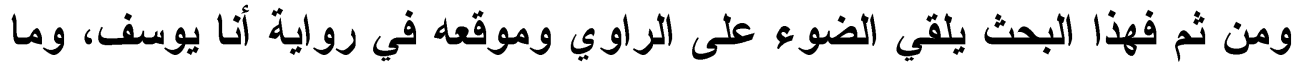

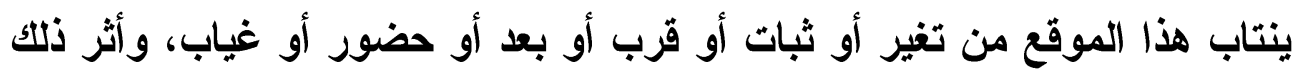
كله على حركة السرد وتغير زوايا النظر وامتداد الروئية .

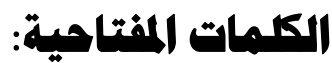

الروية السردية - الراوي - الحضور - الغياب - الموقع - زاوية الروئة - امتداد الروئة - أيمن العتوم - أنا يوسف. 
الروية العردية في رواية أنا يوسف للكاتب أيمن العتوم

\section{Narrative vision in the novel Anna Youssef \\ Written by Ayman Al-Atoum}

Nafisa Mohamed Abdel Fattah

Department of Literature and Criticism - College of Islamic .and Arabic Studies for Girls - Cairo

Email: zaitonah8@azhar.edu.egAbstract

\section{Summary}

Narrative vision is a critical term that defined its way to literary studies related to narration in the early twentieth century, against the background of paying attention to the narrator and his role is no less important than the rest of the components of the novel, including events, time, place and characters, and then this research sheds light on the narrator and his position during the novel of ana Youssef >And what affects this position in terms of change, stability, proximity, distance, presence or absence, and the effect of all this on the movement of narration and changing angles of view.

\section{Key words:}

Narrative vision - narrator - presence - absence - location - angle of vision - vision extension - Ayman Al-Atoum - I am Youssef. 


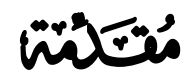

تنظر الدراسات الأدبية الحديثة إلى الروئية السردية والــراوي بوصــهما

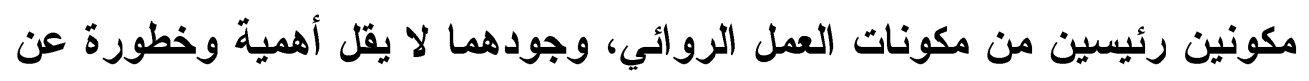

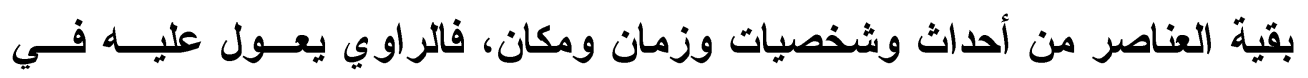

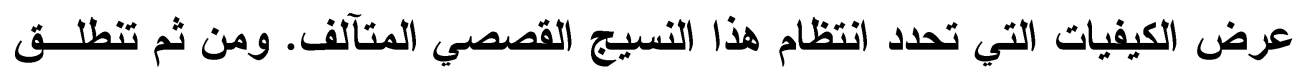
هذه الدراسة من فرضية أن الروئية والراوي وجهان لعملة واحدة؛ فالروئية هـي لهي

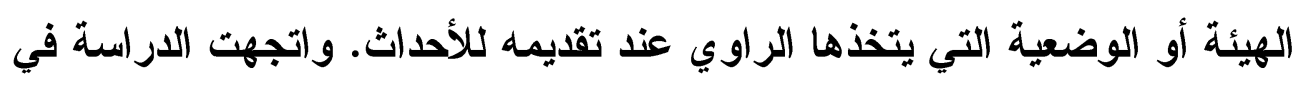

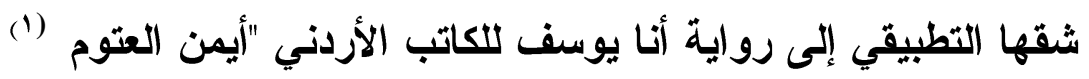

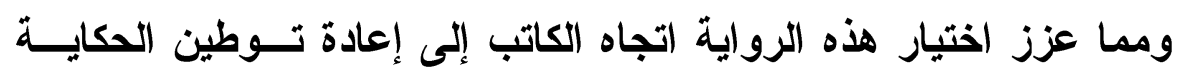

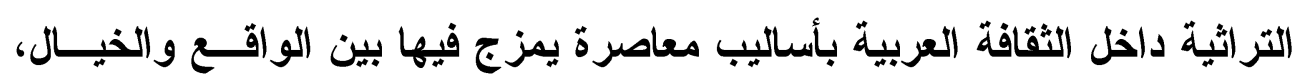

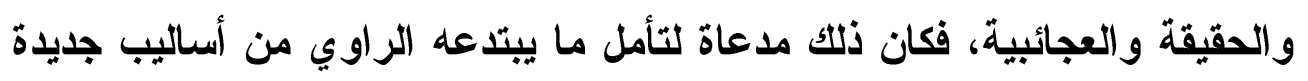

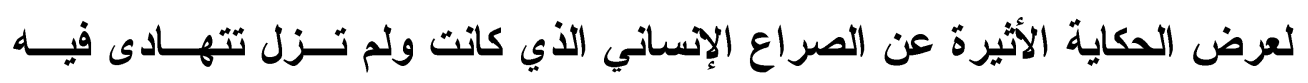

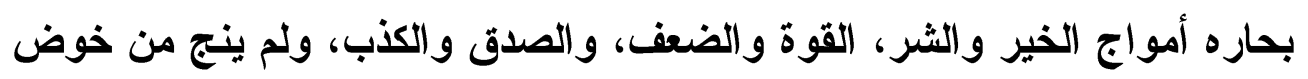

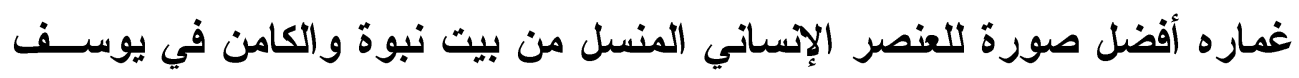

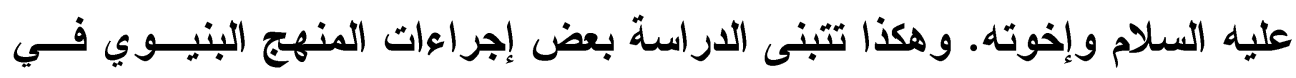
مقاربة الروئة السردية في رواية أنا يوسف اعتمادا على المحاور الآتية:

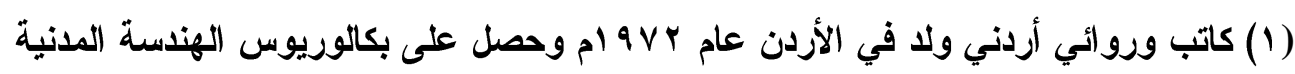

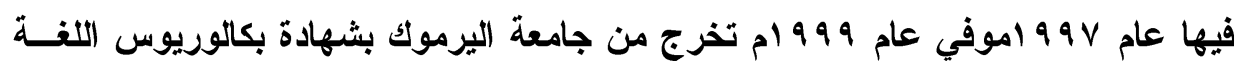

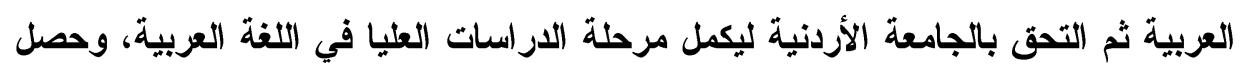

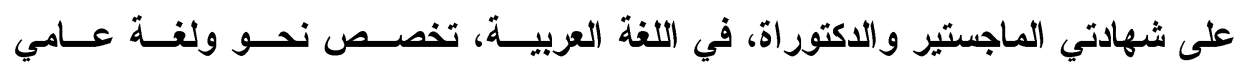

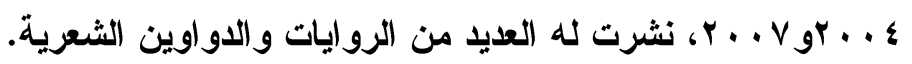




$$
\text { r- ب- هوية الراوي. }
$$

\section{مدخل: الكاتب والراوي}

إن مقاربة الروئية السردية هو في الحقيقة مقاربة المجــاز الأول الــذي يتحتم على كاتب الرواية أن يعبره؛ فروئية الكاتب هي الشعاع الأول الأي تنكشف على إثره تقاسيم الثكل الروائي، فتتحدد هوية الشخصيات وملامحها، وامتدادات الأحداث وسيرورة الزمان وفضاءات المكان؛ فما الفن إلا تصور لوقع العالم على هئ ذات المبدع إما تماهيا معه أو تمردا عليه، ومن ثم" فشعور الكاتب بنــوع العــالم

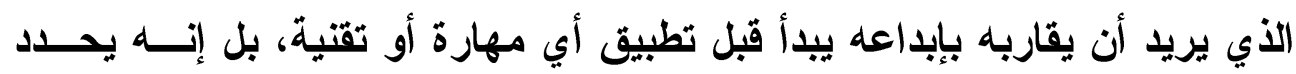

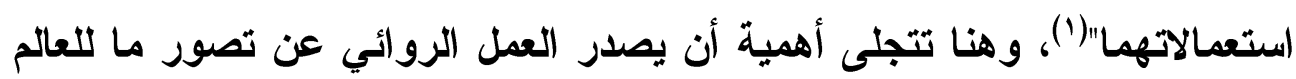
أو الذات؛ فقي عالم الرواية لا تتواتر الوقائع خبط عشواء وإنمـــا وفـثق رؤيسـة

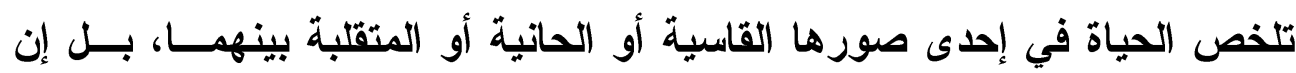
"رؤيتين مختلفتين لواقعة واحدة تجعلان منها واقعتين متمايزتين، ويختــف كـلـل

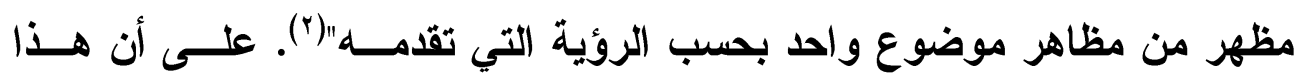

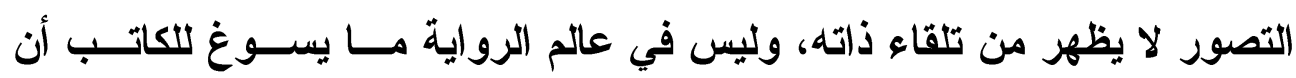
يظهر بين ثنايا النص ليلقيه بنفسه؛ فالروائي هو صانع العالم السردي هو الــــي يختار الشخصيات ويوجه الأحداث لكنه لا يظهر في المجال السردي بثكل مباشر

(1) جون هالبرين، نظرية الرواية صوج ؟؛، ت محيي الدين صبحي، منشورات وزارة الثقافة،

$$
\text { دمشق، }
$$

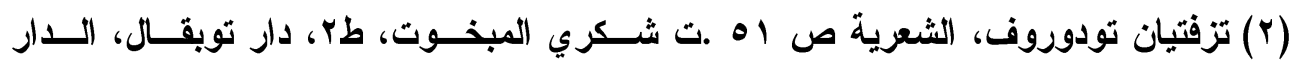

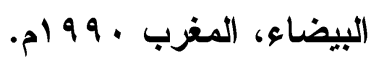




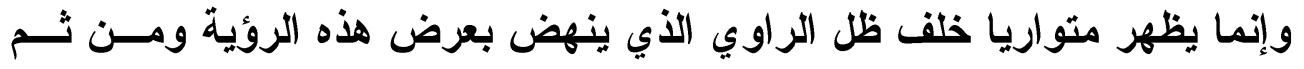

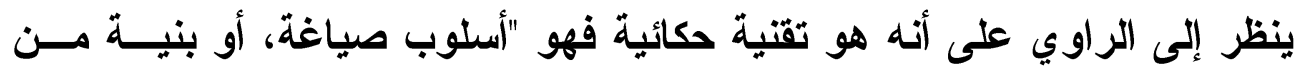

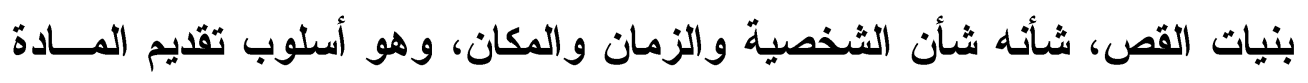

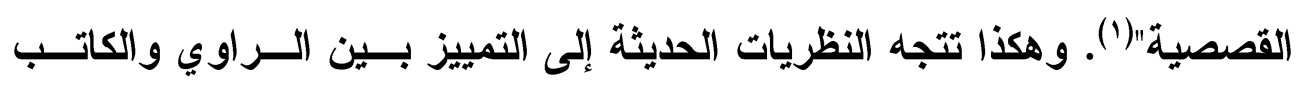

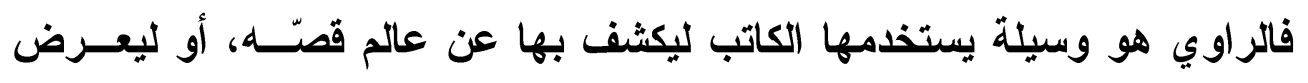

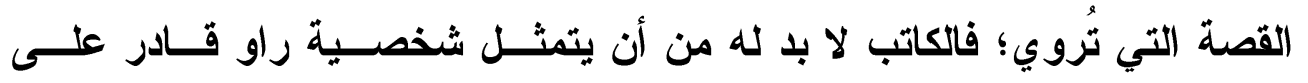

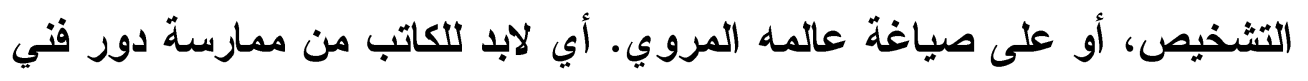

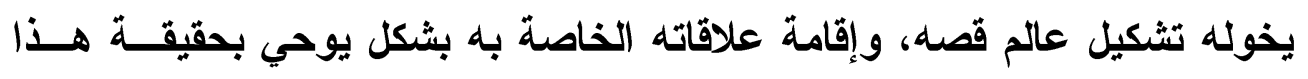

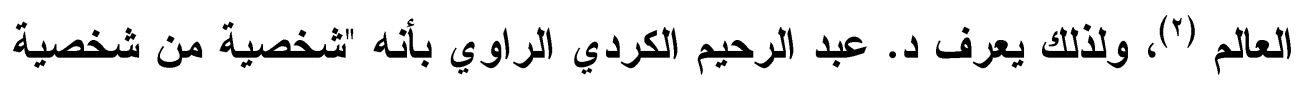

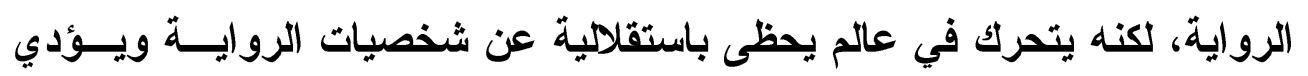

وظائف تختلف عنها".(涫) أما عن الروئية السردية فهي تكثف عن الوضعية التي يتخـــها الــــاوي

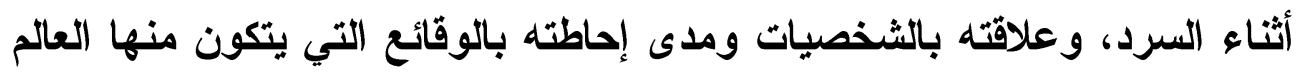

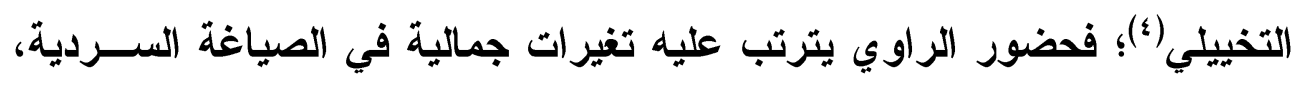

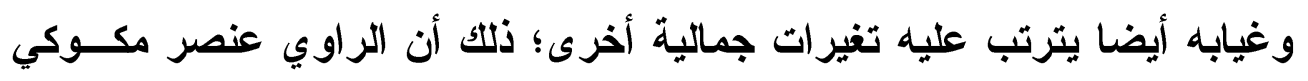

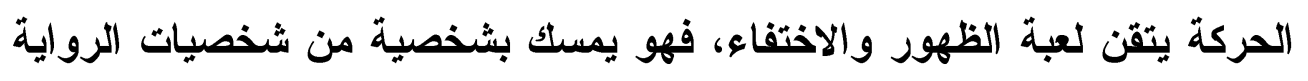

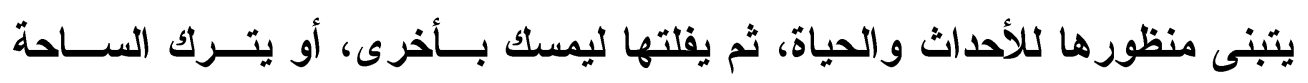

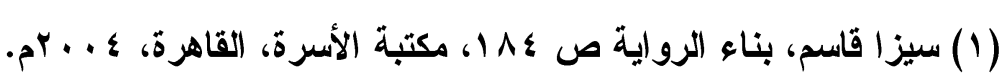

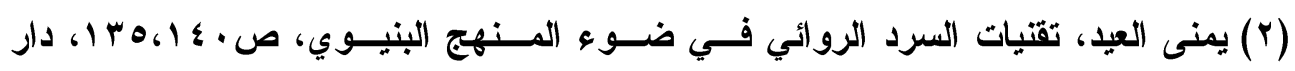

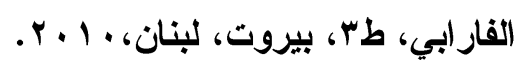

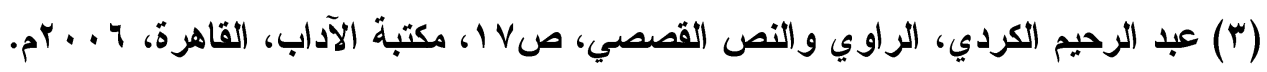

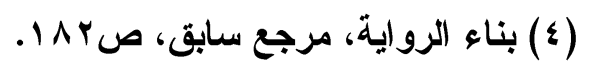


للثخصيات، ويختفي ثم يظهر من جديد، يصـــ بالأحسـاث أو يهـبط، يهــادن،

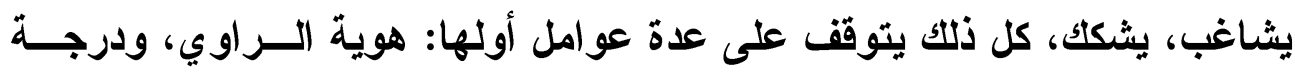

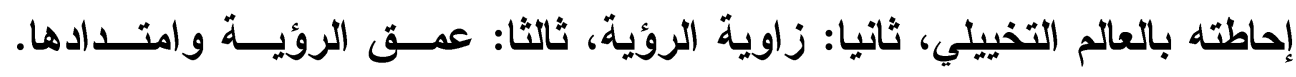

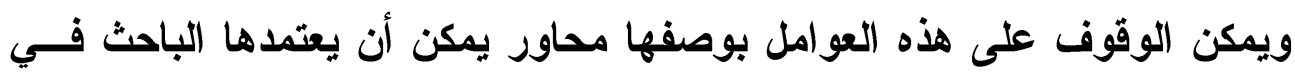
دراسة الروية السردية في رواية (أنا يوسف).

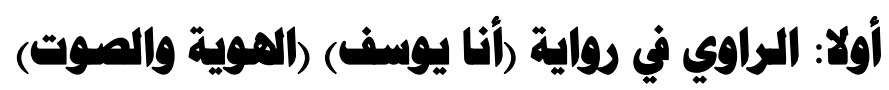
لقد خرجت الدراسات الحديثة في إطار اهتمامها بالر اوي بتصنيفات كثيرة

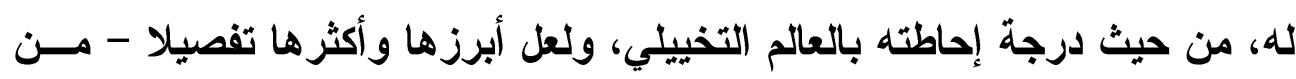

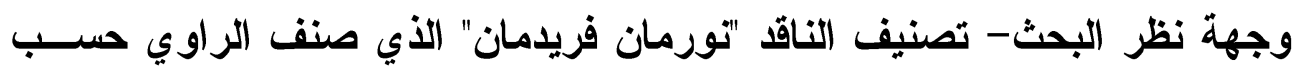

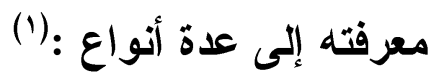

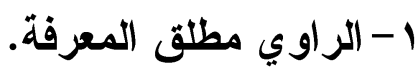
ץ - الراوي المحايد، وهنا يتكلم الز اوي بضمير الغائب، ولا يتلخل في الأحداث

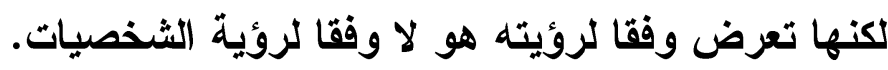

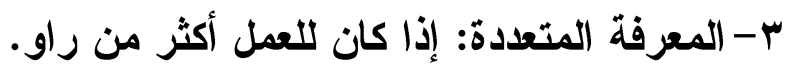

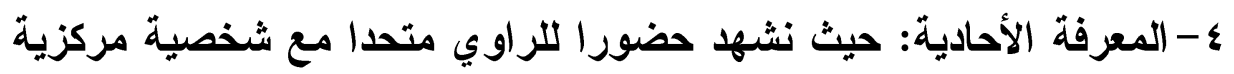
يعرض الأحداث من خلالها. ه- الأنا الثاهل: حيث يظهر الراوي بضمير المتكلم مستقلا عن الثخصيات، وتصل الأحداث إلى المتلقي عبر الراوي ولكنها من محيط متنوع. צ-الأنا المشارك: الراوي هنا شخصية محورية في الرواية.

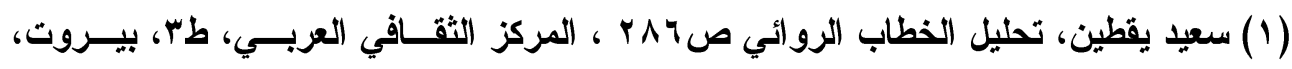

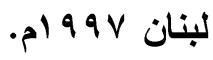


ويضع الناقد الفرنسي "جان بويون"(1) ثلاثة أصناف رئيسة تنظم العلاقــة

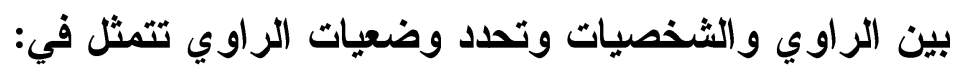

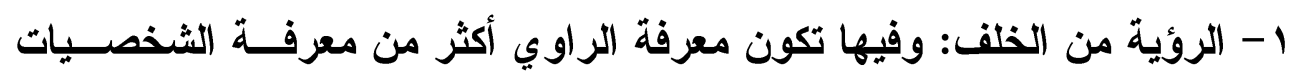
حيث يظهر ما يسمى بالر اوي العليم، وتكون الحكاية بضمير الغائب.

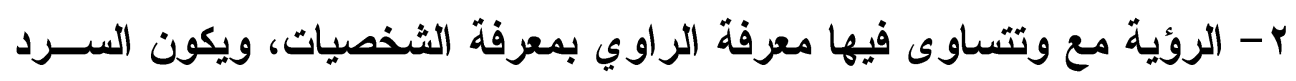
بضمير المخاطب.

وجملة القول: إن الراوي أحد نوعين: إمـا أن يكون مشاركا فــي أحسداث

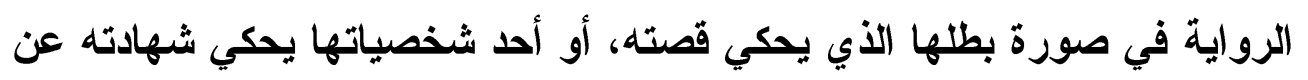

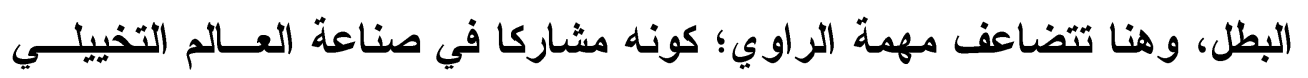

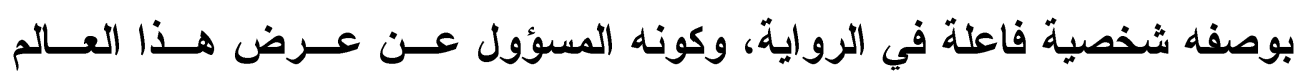

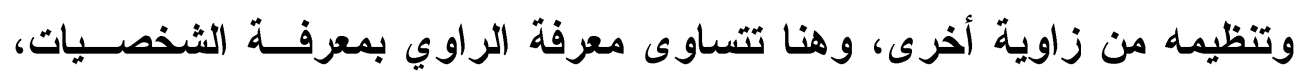

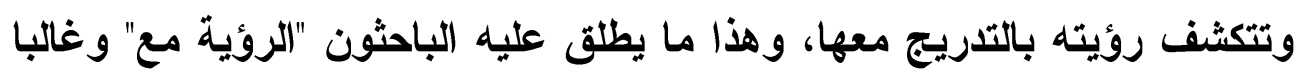

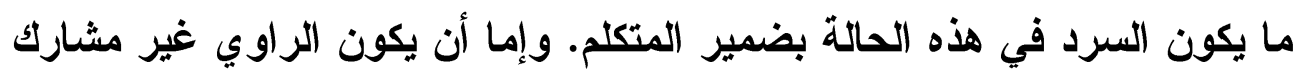

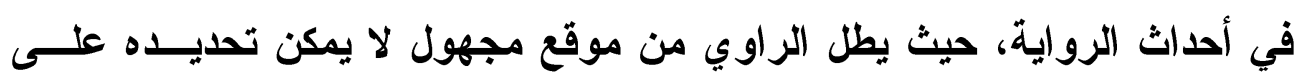

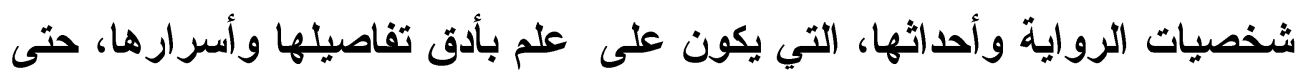

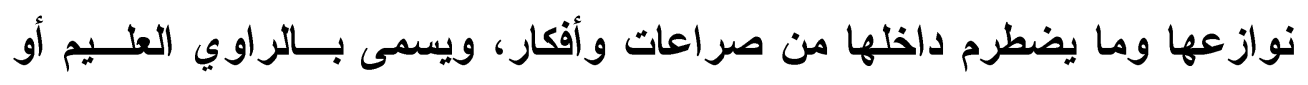

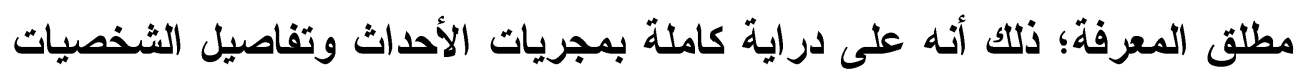

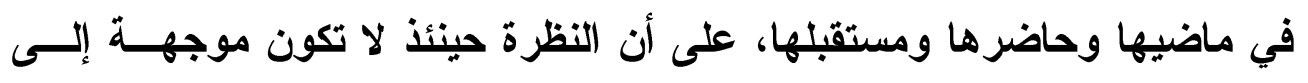

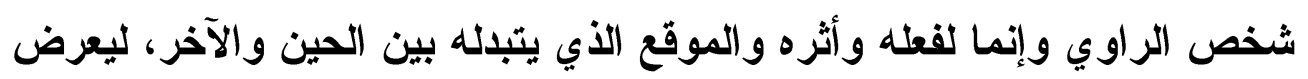

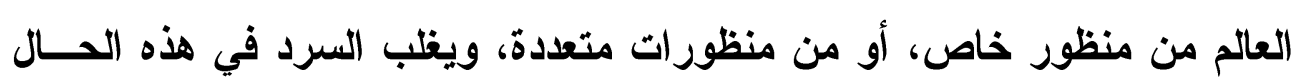
بضميري الغائب و الخطاب.

(1) سيزا قاسم، بناء الرواية، مرجع سابق، ص ع ^1. 


\section{الروئية السردية في رواية أنا يوسف للكاتب أيمن العتوم}

وفي رواية "أنا يوسف" ينتمي الراوي إلى الصنف الثاني، فالراوي لـيس

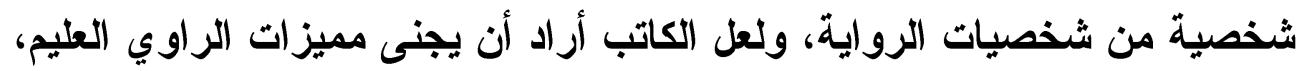

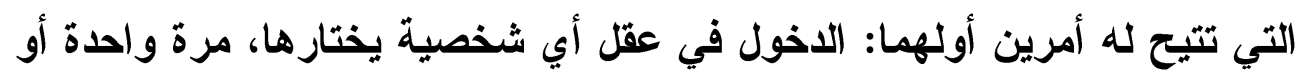

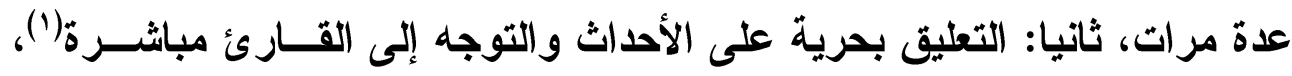

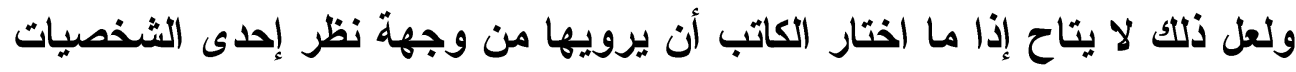

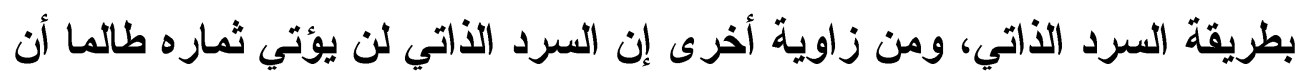

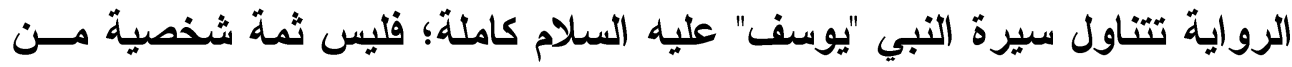

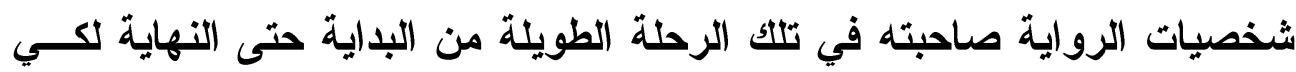
تروي عنه، سواء و الايه أو إخوته أو حتى في مصر أو السجن، إنما كانت حياته لتهنه

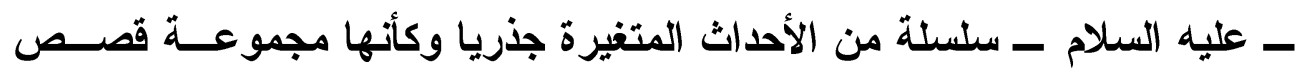
منفصلة الثابت فيها هو بطلها. ثانيا: زاوية الروية

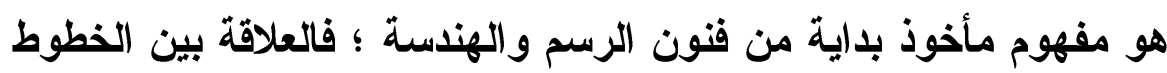

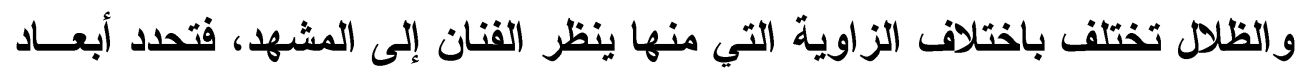

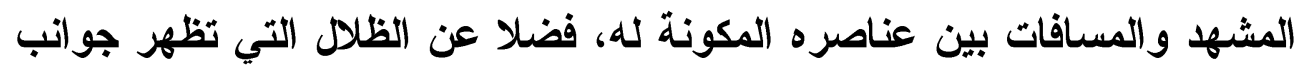

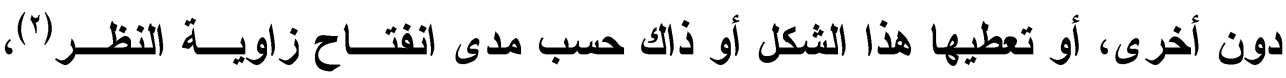

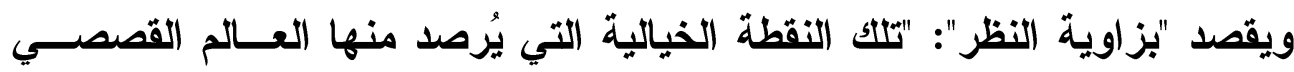
المتضمن في القصة"(")، ويرى الباحث "عبد الرحيم الكردي" أنه يمكن تحديد معالم

(1) ناتسي كريس تقتيات كتابة الرواية ص r ع ب ت زينة جابر إدريس الار العربيــة للعــوم

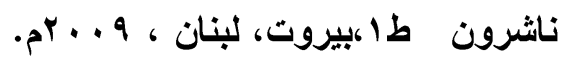

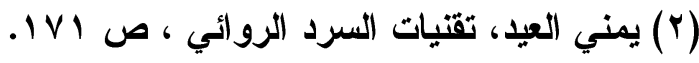

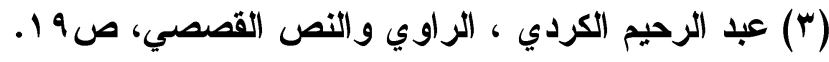


الروئية السردية داخل العالم المتخيل اعتمادا على أسس ثلاث: أولهــا: الموقــع،

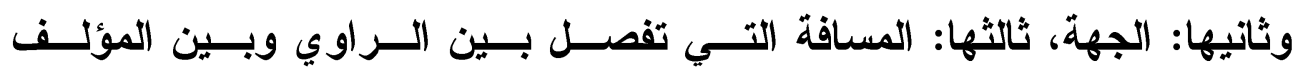

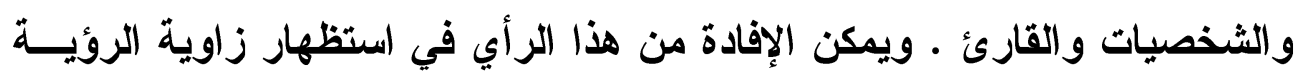

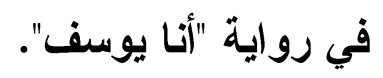
أ- الإمقع : في روايه

إن الروئة التي يعرضها الراوي تختلف باختلاف موقعها الذي تصدر عنه؛

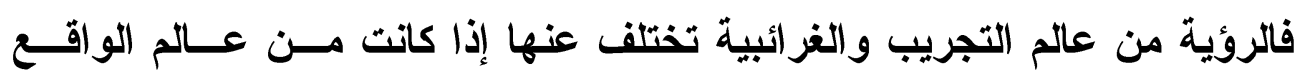

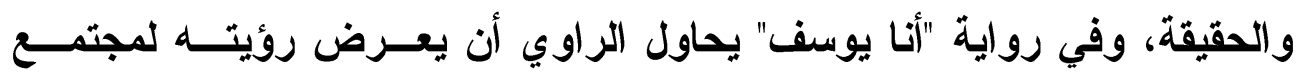

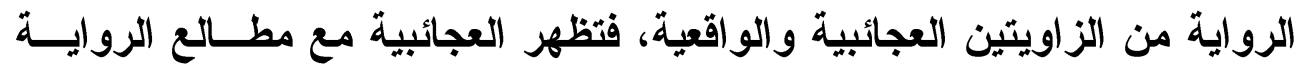

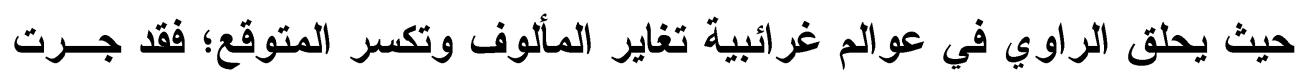

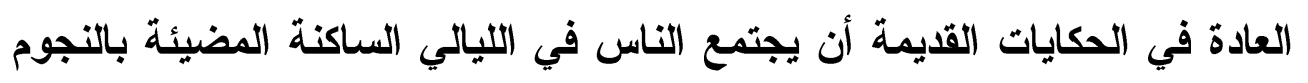

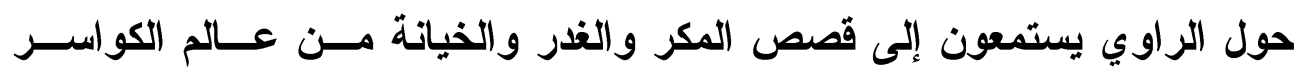
و الوحوش والأئاب، ولكن الراوي يكسر هذا التقليد أو بمعنى أصح يعكسه، فيُظهر

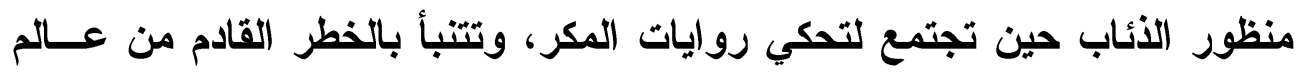

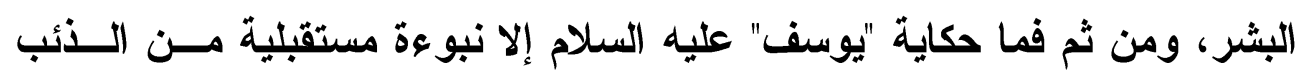

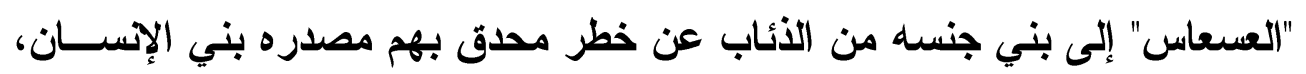

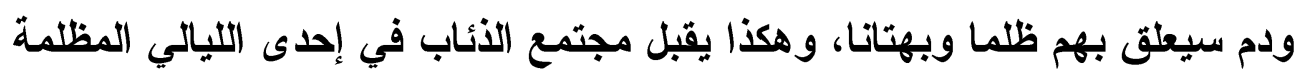

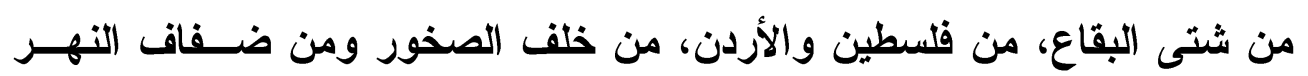

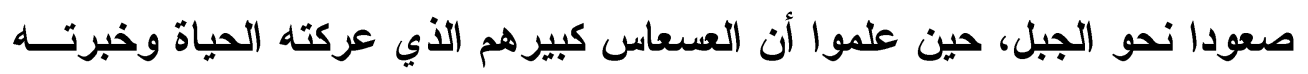

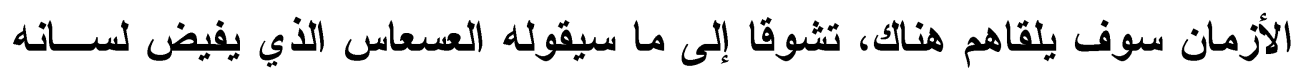

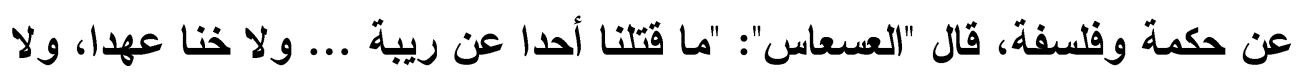

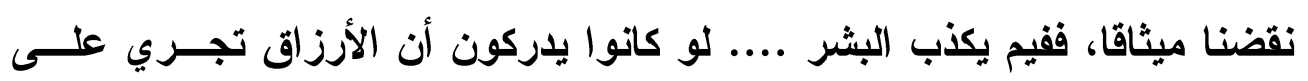


الأقدار لما اقتتلوا، هل المحبة إلا رزق؟ وهل الإيمان إلا رزق؟ لكنهم لما تركـــوا

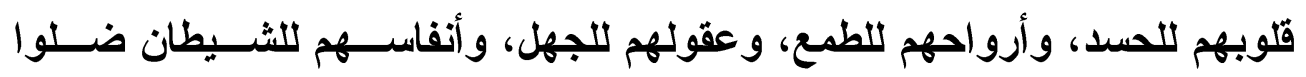

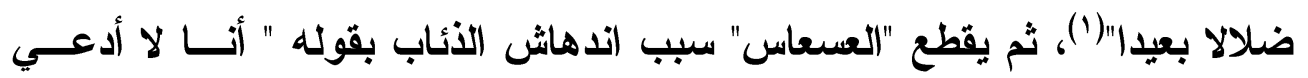

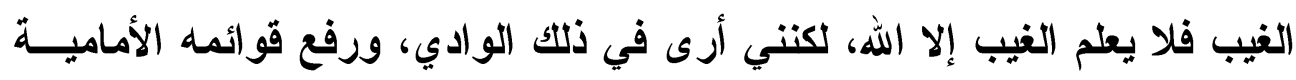

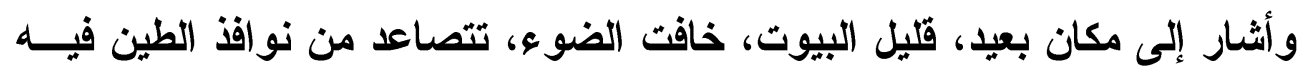

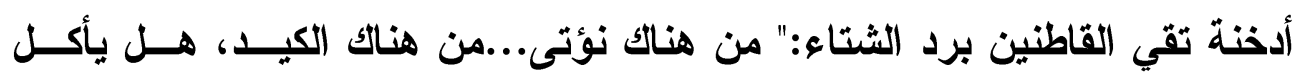

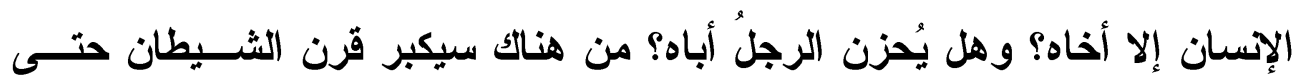

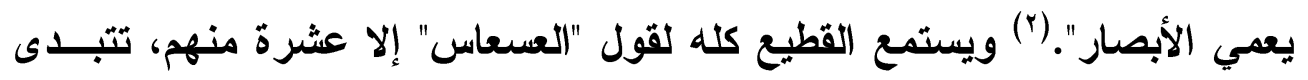

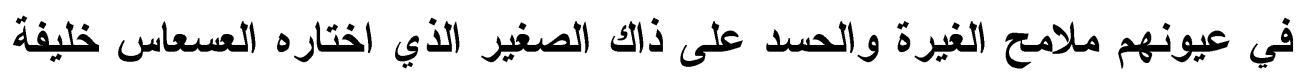

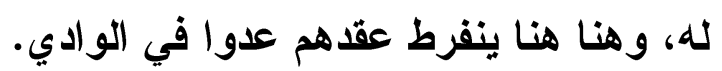

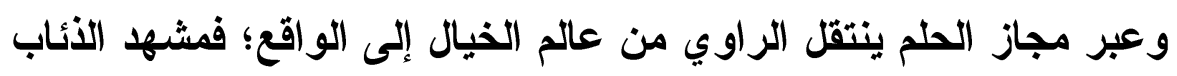

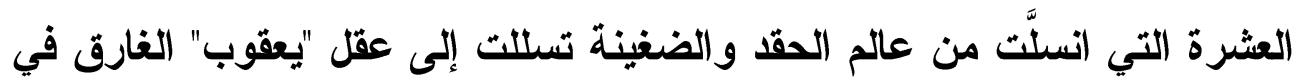

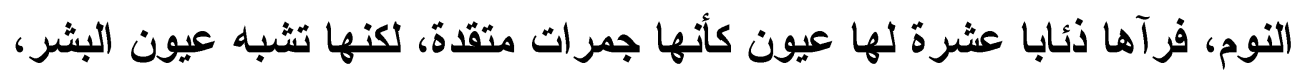

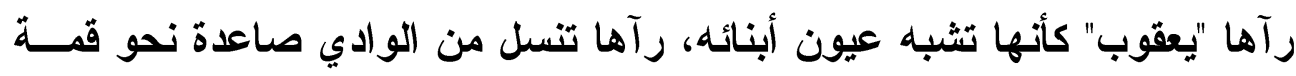

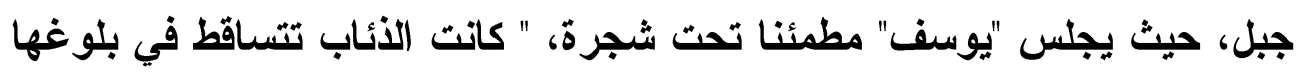

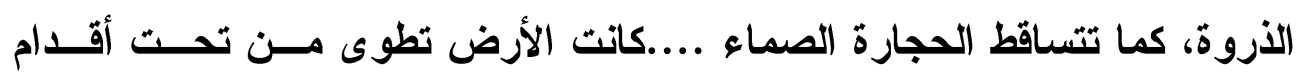

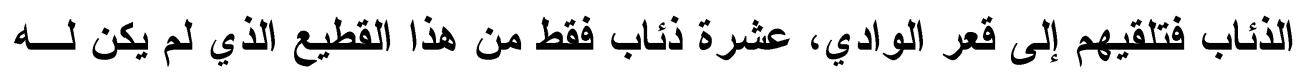

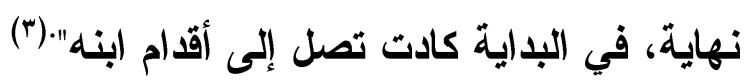

(1) أيمن العتوم، رواية أنا يوسف، ص^ی، دار المعرفة، طا، القاهرة، 19 ـ بم.

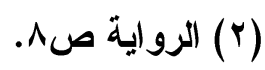

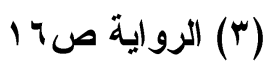


وأما الزاوية الواقعية التي يرصد منها الراوي عالمه التخييلي فتتمثل في

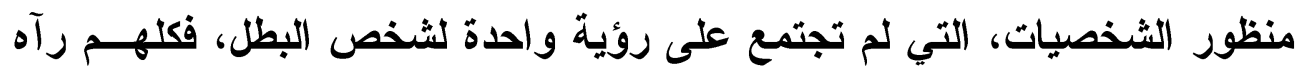

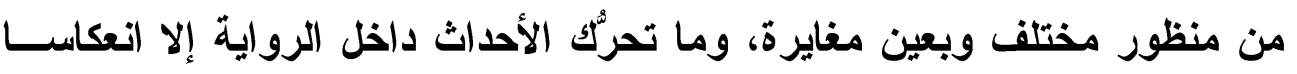

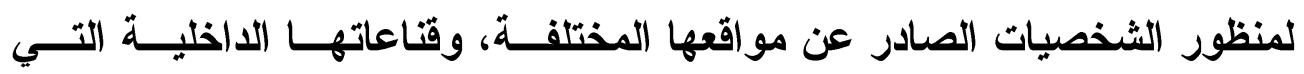

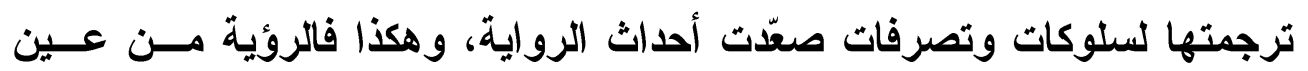

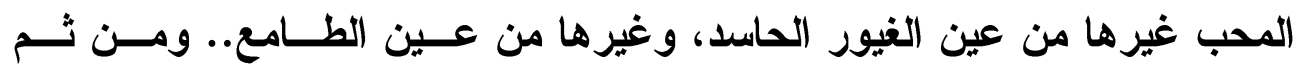

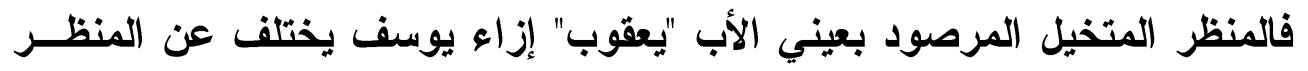

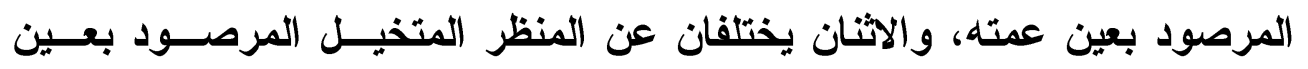

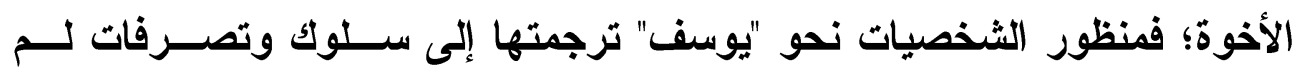
تتثابه، لكنها أثرت في تطور الأحداث، فالعمة دفعها التعلق بيوسف إلى إلى الادعـاء

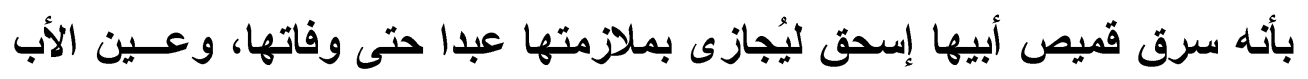

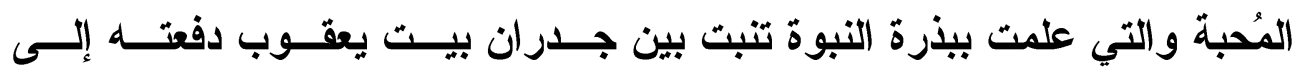

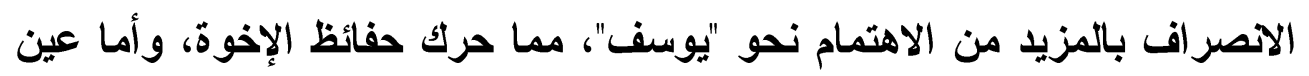

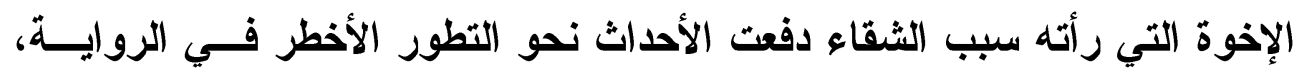
لأنه أدى إلى تغير مجرى الأحداث على مدى أكثر من أربعين عاما.

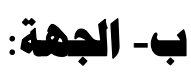

من المهام التي يضطع بها الراوي أن يعيد الحياة المتخيلة للثخصـيات

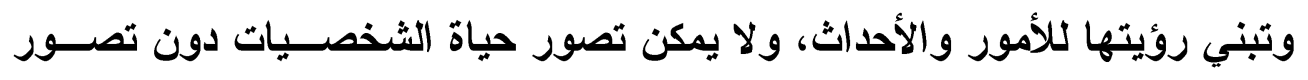

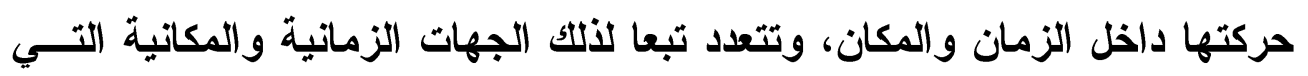
يمكن أن يقف فيها الر اوي: 


\section{البهات المكانية:}

يصاحب الراوي الشخصية ويبدو وكأنه ملازم لها بصورة مؤقتة، أو على طول السرد وبذلك يحتل الموقع المكاني الأي تحتله تلك الثخصية، فحين تـدخل الشخصية غرفة ما يصور الراوي الغرفة، وحين تخرج إلى الشارع يصور الراوي الشارع، متبنيا أنظمتها الفكرية والنفسية، حتى تنكشف وجهة النظر مـن تلقــاء نفسها")، وهكذا بين بادية كنعان وحاضرة مصر وما بينهما من صحر اء الجـب

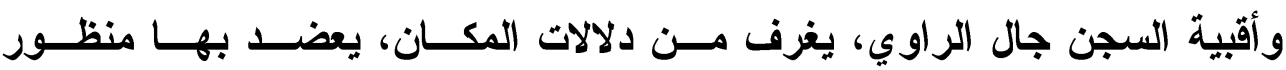
الشخصيات وينيتها الاهنية والنفسية؛ فالصحراء صحراء الخطيئة والندم، والبئر و السجن مدرسة النبوة، ومنبع الضياء، وعلى المدى بينهمــا صــاحب الـــــاوي شخصياته، أشعل القناديل داخل الغرف، ليكثف عما دار فيها من فورة الخطيئة، وسنورة الشيطان، وصاحب الإخوة في الصحراع، ولون الشمس بألوان غاضــبة، وهبط مـع "يوسفت" إلى عمق البئر، وصور ظلمتــهـه وهوامــه وأفاعيــه، وكــوخ "يعقوب" الأي اعتزل فيه أبناءه، ونثر الكؤوس والراح داخل القصر، وأسمع رنين الضحكات في الأبهاء، وروى نبتة الحزن التي بزغت في قلب "يعقوب"، وشــرة الندم التي أظلت الأبناء أكثر من أربعين سنة. وفى الرواية ما يدل على حرص الراوي على أن يعكس تجاوب الفضاعات المختلفة مع انفعالات الشخصيات بما يسهم في بلورة منظور اتها، ومن هذا القبيل خروج "روبيل" مسرعا هاربا من حجرة إخوته بعد فشله في إثنائهم عن مخط ط قتل "يوسف"، فبكى وصرخ: " لماذا؟؟!..." صعدت صرخته إلى السماء وارتطمـــ بالنجوم. بالمجرات. ترددت بينها ككرة معدنية مصــمتة ضـــمة، مــلأ صــــاها

(1) بوريس أوسبنسكي، شعرية التأليف، ص9 جا، ت سعيد الغانمي، المجلس الأعلى للثقافـة،

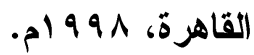


المشرقين. تجولت عشرة آلاف عام في المدارات، أبكت كل كوكب سيار. وعادت

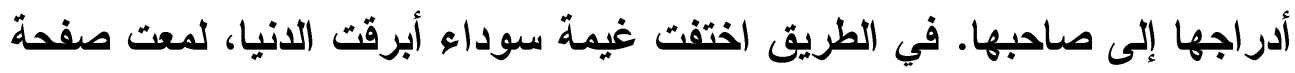
في الفضاء. قصف صوت الرعد وهطلت الغمامة، سحت كأنها تخزن ذلك البكــاء

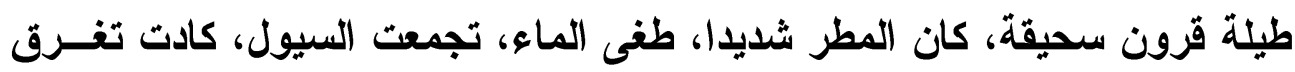

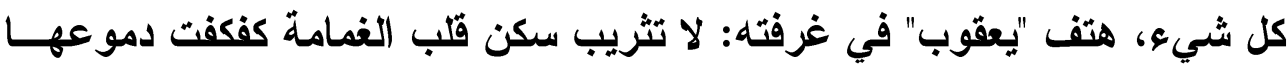

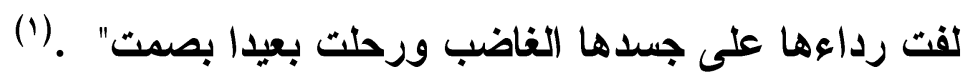

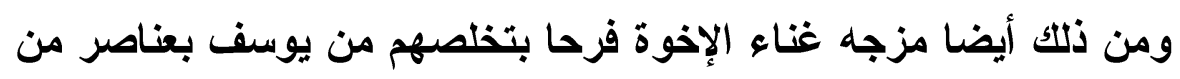

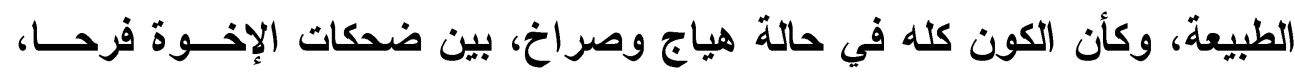

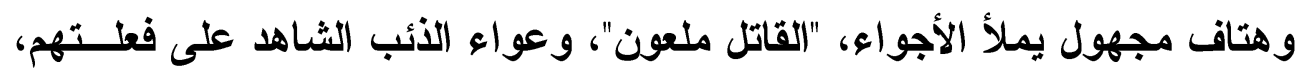

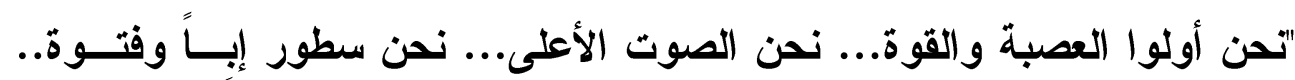

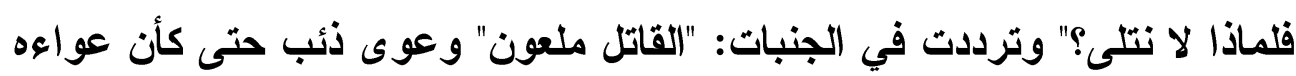

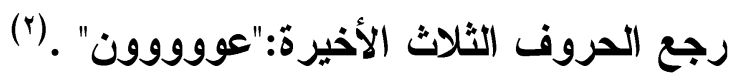

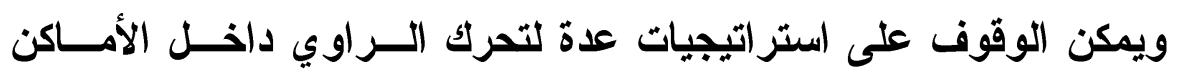

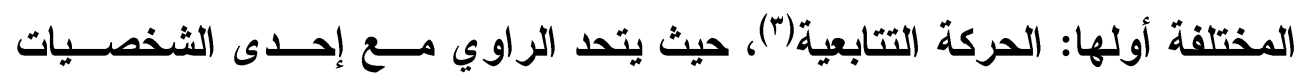

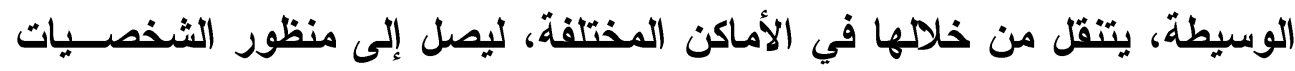

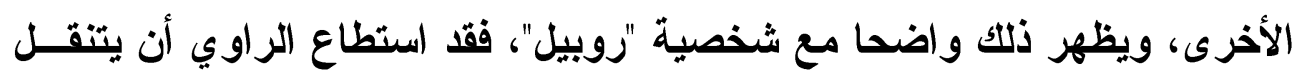
من خلالها بين غرفة الإخوة، وبين حجرة "يعقوب"، وبين حجرة "يوسف"، ثم إلى

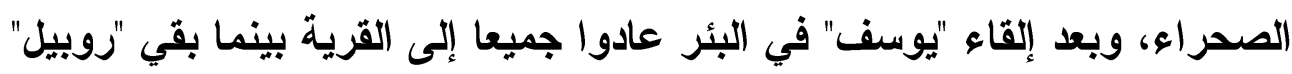
يراقب "يوسف" ويرسل إليه الطعام على مدى أربعة أيام، حتى شاهد القافلة ترحل

$$
\begin{aligned}
& \text { (1) الرواية ص VV. }
\end{aligned}
$$

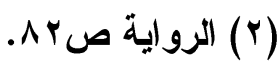

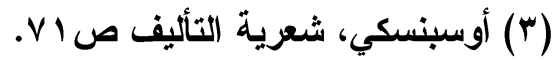


به إلى مصر، ولعل هذا ما يفسر ظهور روبيل في كثير من المشاهد، وفي مصـر

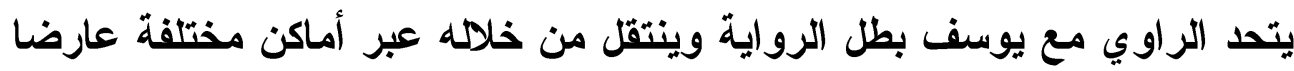

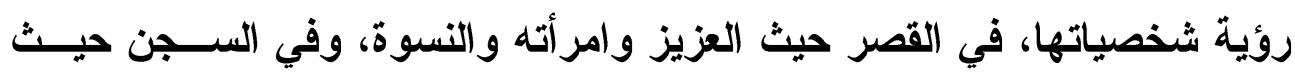

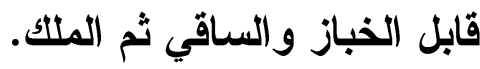

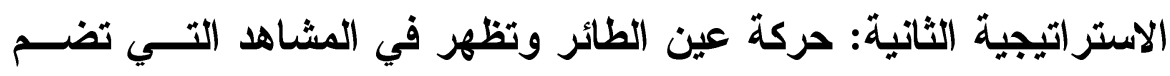

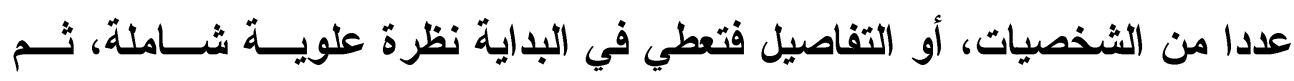

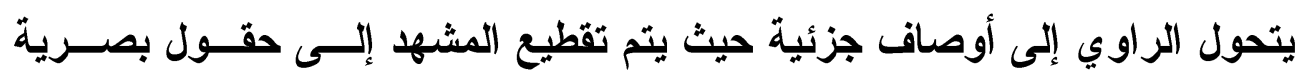

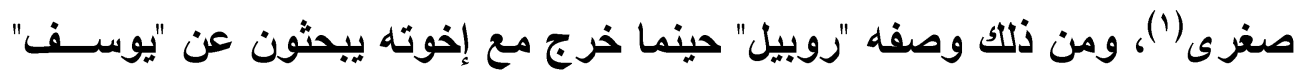

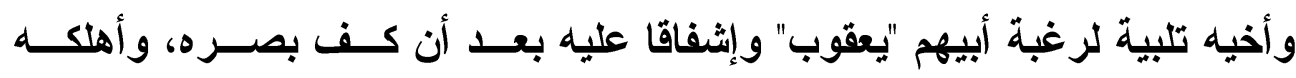

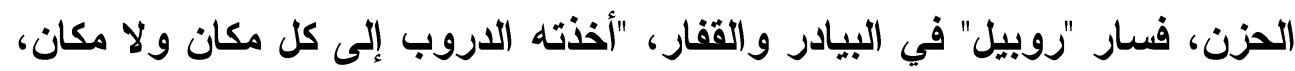

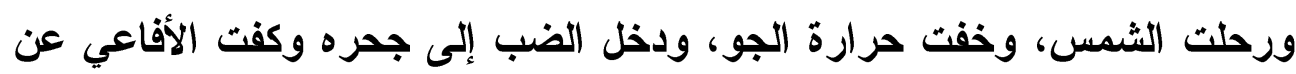

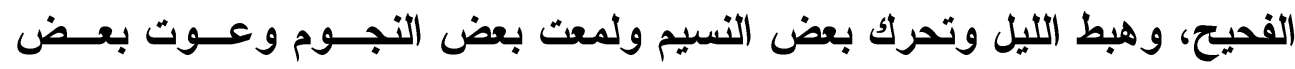

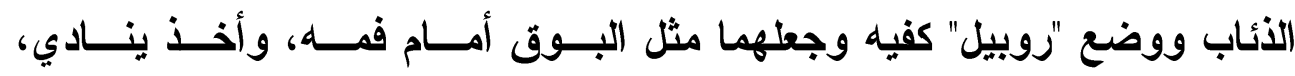

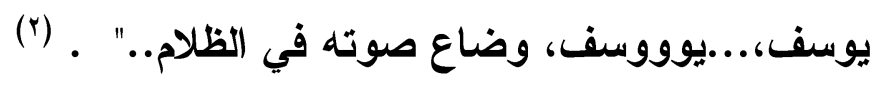

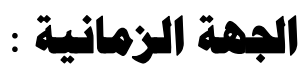

من الملاحظ أن الرواية غنية بالتقتيات الزمنية التي تعددت علــى إثرهــا

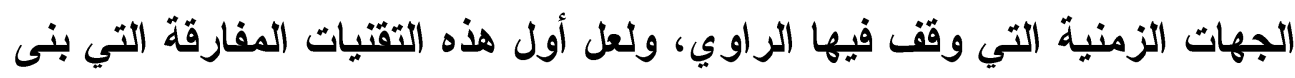

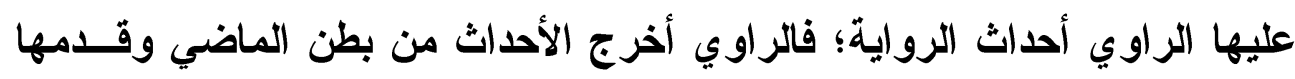

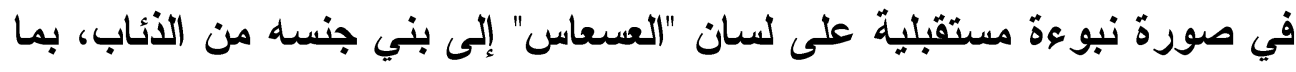

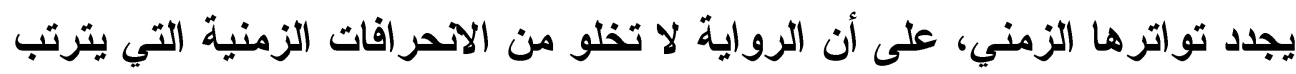

(1) أوسبنسكي، شعرية التأليف، مرجع سابق ص هV. V.

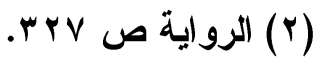


عليها وقوف الراوي في جهات زمنية سابقة لأوانها، فتـأتي الحكايــة بصـيغة

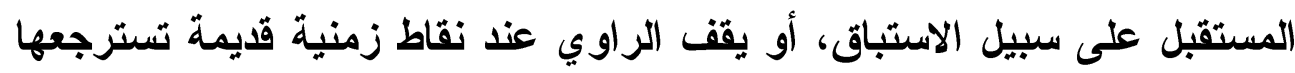

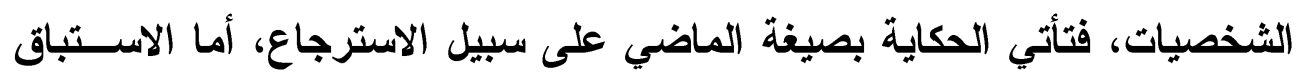

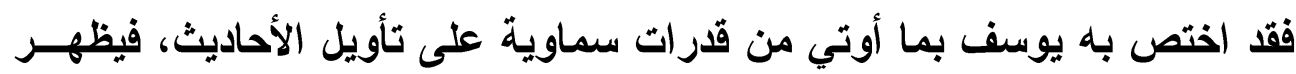

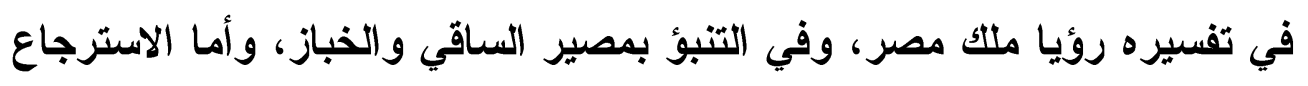

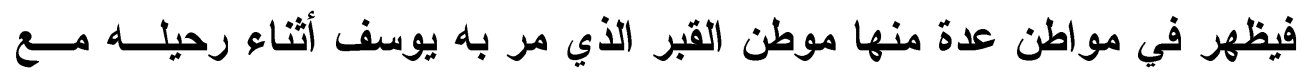

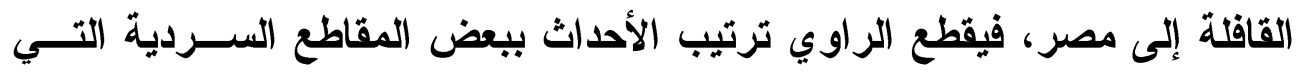

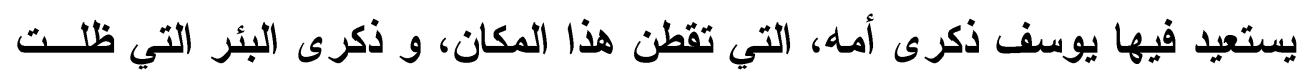

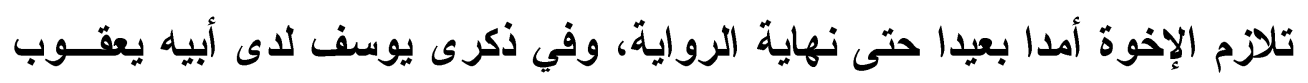
وأخيه بنيامين . تلغم الاخدة وبمقارنة النظام الزمني للأحداث كما وردت في الرواية وبين نظامها فـي

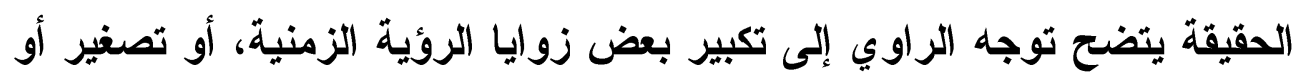

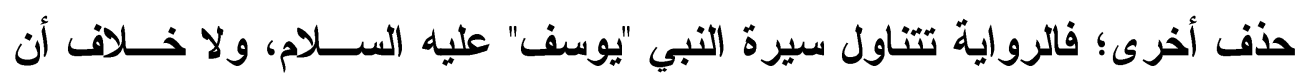

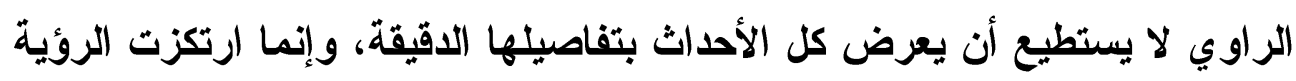

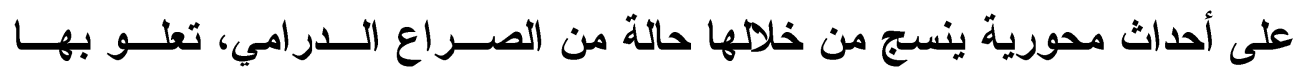

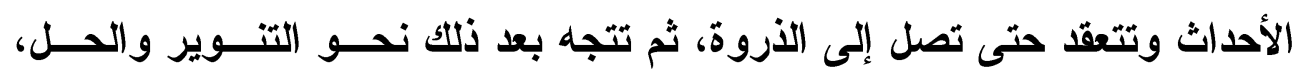

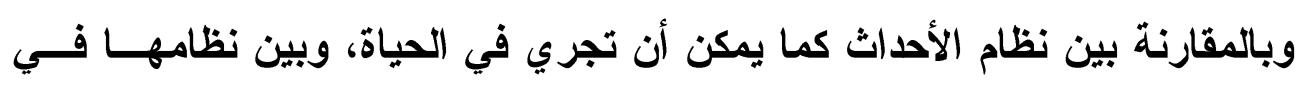

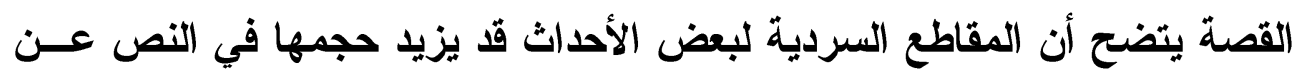

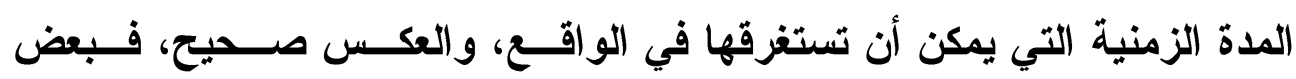

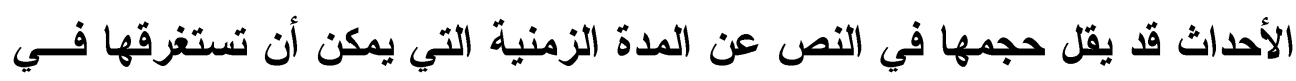
الحقيقة كما يتضح من الجدول: 
الروية السردية في رواية أنا يوسف للكاتب أيمن العتوم

\begin{tabular}{|c|c|c|}
\hline في الرواية & في القصة & الحدث \\
\hline • 0 صفحة & اثنا عشر عاما & طقولة يوسف \\
\hline V V صحة & أربعة أيام & حادثة الجب \\
\hline . ع صفحة & عشرين عاما & البلوغ و الثباب \\
\hline ع Vفحة V ص & عشر سنين & السجن \\
\hline V Vفحة V . & سبع سنين & التمكين \\
\hline
\end{tabular}

من الجدول السابق يتضح أن طفولة "يوسف" حتى خروجه من كنعان إلى

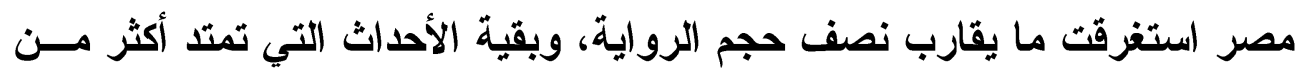
أربعين عاما في نصفها الآخر، وحادثة الجب على الرغم من قصر مدتها الزمنية،

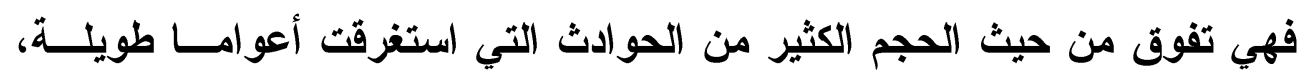
ولعل ذلك يشير إلى أن روئة الكاتب ارتكزت بشكل أكبر على الظلال الرمادية التي أحاطت بحادثة التآمر، وأن التدبير لتتلك الحادثة من قبل الإخوة لم يكن وليد عشية وضحاها، ومن ثم فصراع الإخوة كان هو الأكبر وهو في الحقيقة لم يكن صراعا

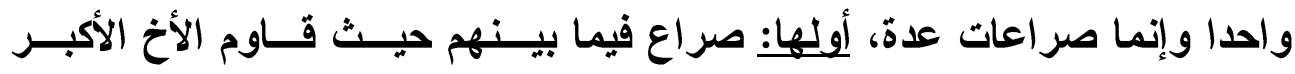
"روبيل" الأي ورث عن أبيه يعقوب لين القلب رغبة الإخوة بزعامة "يهوذا" فـي

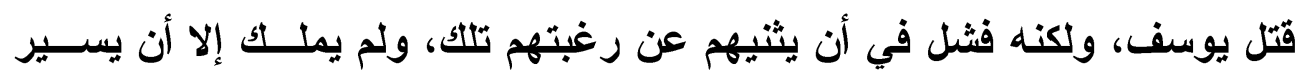
معهم في تحقيق نواياهم، اللهم إلا أنه احتال إليهم بعد أن ألقوا الطفل في البئــر

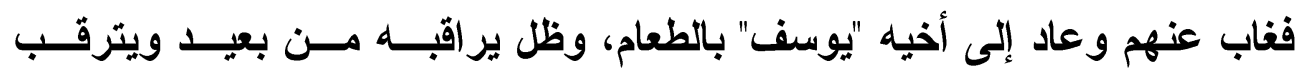


خروجه حتى جاعت القافلة وحملته، ويصور الراوي قوة "يهوذا" وجبروتــه فـي

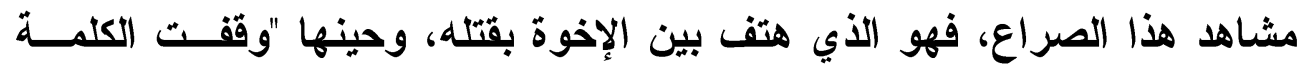

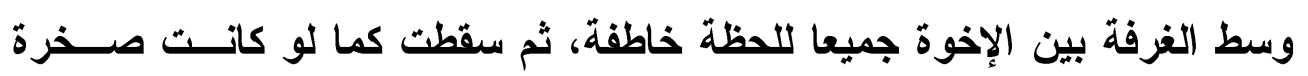
ثقيلة هرست أقدامهم جميعا، وتفتت إلى قطع صغيرة محماة، ثم ارتدت فذخلت إلى الإن

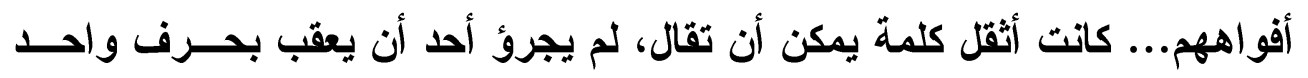
سواه، سوى "يهوذا" الذي راح ينظر في وجوههم ويطوف عليهم واحدا واحــا: "نعم سنقتله..." (1)

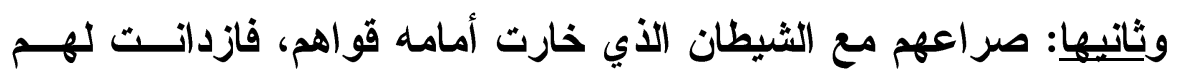
الرزيلة، وهانت أعينهم حجم الجريمة، عبر الراوي بذلك على لسان "روبيل" الأخ الأكبر، "أسمع صوت الثيطان في كلماتكم، الثيطان الأي امتلأت به روح قابيـلـل أشم خبثه في حديثكم، أمعقول أن التبي "يعقوب" هو أبوكم...لماذا تزاحمون القدر

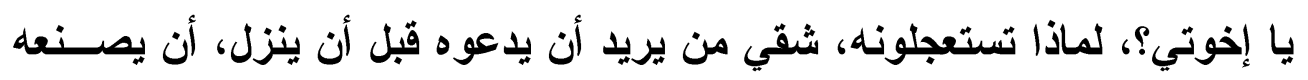

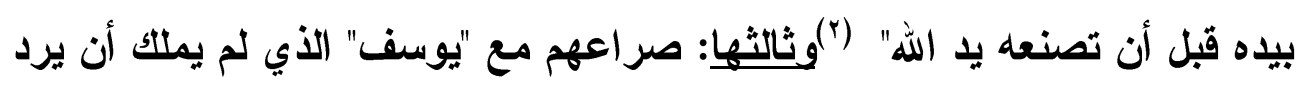

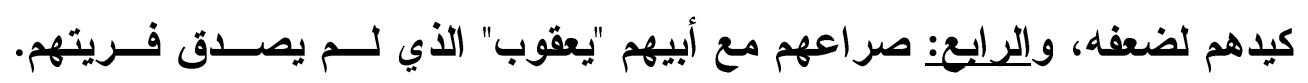

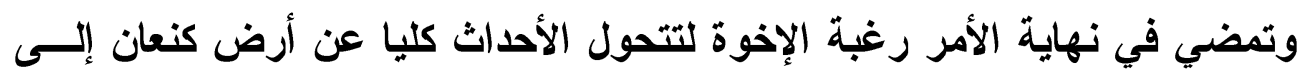
حاضرة مصر. ويطوي الر اوي سنوات البلوغ والثباب في مصر، فعشــرين ســنة فــي

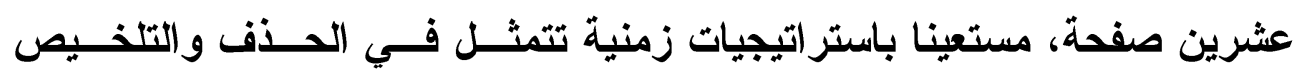
تجسدها تعبيرات مثل" الساقية تدور، من يوقف الساقية؟ الزمن يجري كأنه غزال هارب، من يوقف الغزال؟ العمر ينسرب كأنه ماء تسلل من تحت شث صخرة، من

$$
\begin{aligned}
& \text { (1) (الرواية ص ع ه. }
\end{aligned}
$$

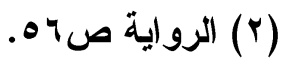


(1)

$$
\text { بجمع - الماء؟" }
$$

هناك علاقة بين ظهور صوت الراوي وبين المسافة التي تفصــله عـن الشخصيات، وعن المؤلف، وعن القارئ، بمعنى أن الراوي يقف في منطقة مـــا من كل هذه الجهات بين المؤلف وبين الشخصيات وبين القارئ، وكلمــا اقتــرب الراوي من الثخصيات وابتعد عن المؤلف تضاعلت صــورته، وخفــت صـــته وتلاشت لهجته، وقلت سطوته، وكلما ابتعد عنها واقترب من المؤلف ومن القارئ

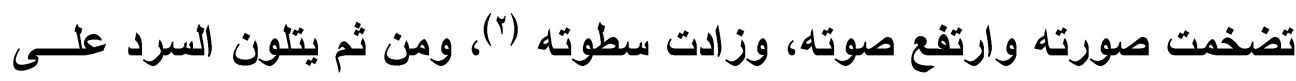

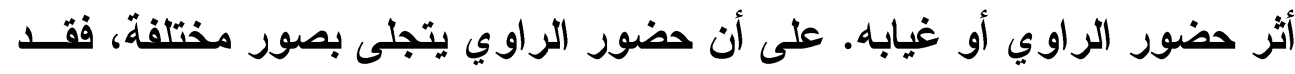
يظهر مستقلا في سرد الأحداث ورصد حركة الشخصيات ودلالاتهــا وســوكاتها المختلفة، ويظهر مقتربا من المؤلف في عدة مظاهر، أولها: الوصف الذي يحمل

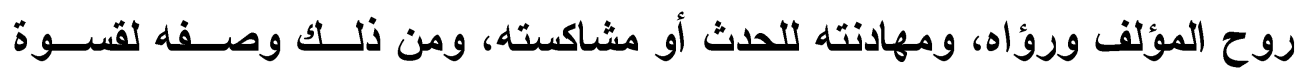
سلوك "يهوذا"، ومكره بأبيه "يعقوب" وبيوسف، وتعاطفه مع "يوسف" إزاء قسوة الأخ، فيصف خروج الإخوة بيوسف "حمل "يهوذا" "يوسف" بين كتفيه، قــال لــهـ:

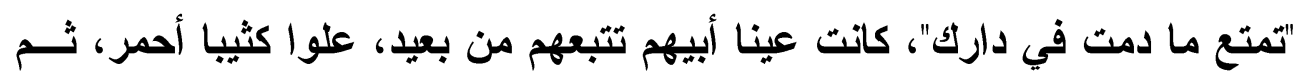
هبطوا فهبط قلب يعقوب معهم، ثم اختفوا عن ناظريه، فلما تأكد يهوذا أن عيـون أبيهم لا تراهم، أمسك "يوسف" بيديه فرماه من فوق أكتافه إلى الأرض، فــارتطم

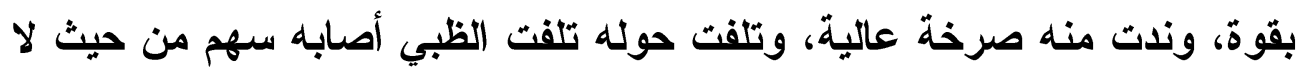
يلري، وتأوه من الألم تأوه اليتيم لم يجد من يتعهده"()، وفي وصفه لمصير مالكك

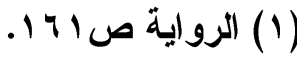

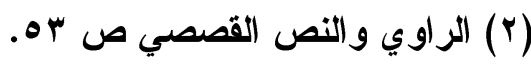

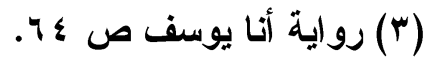




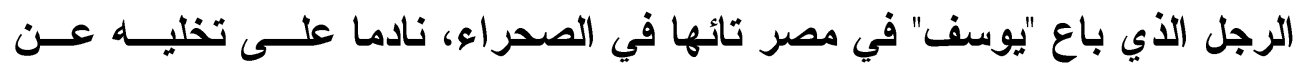

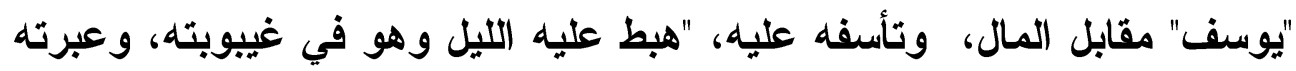

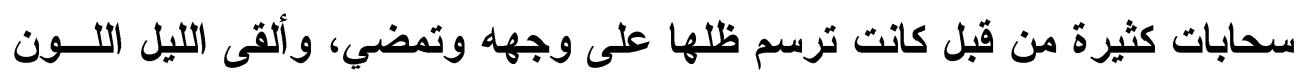

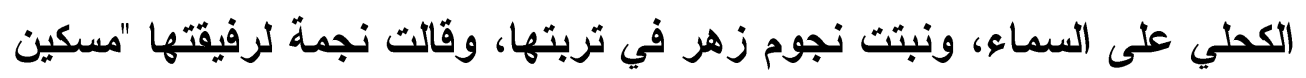

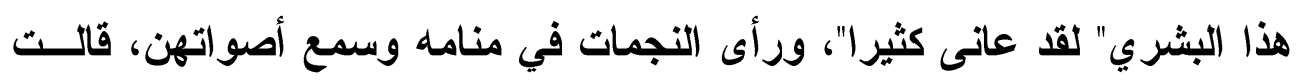

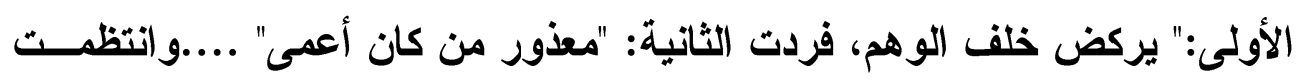

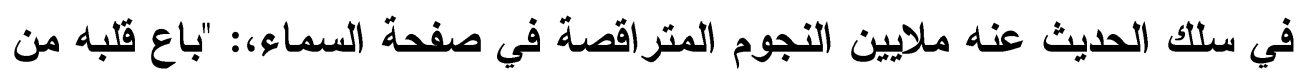

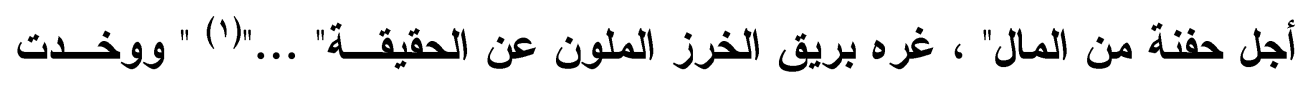

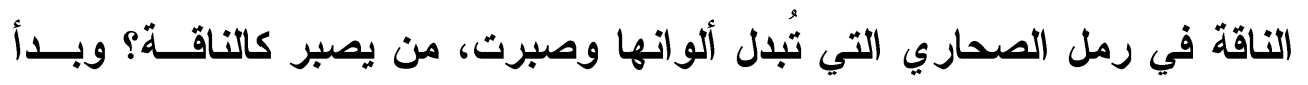

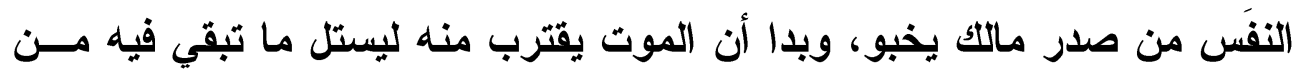

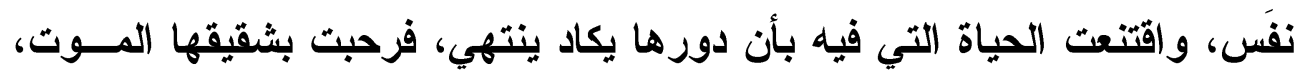

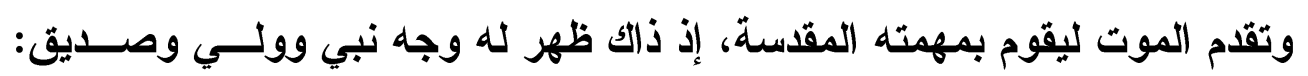

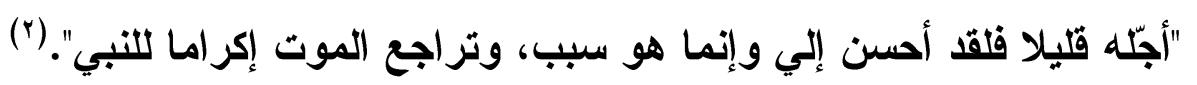

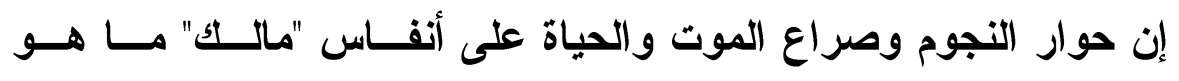

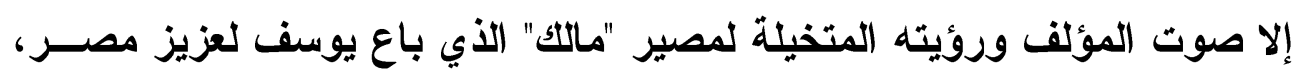

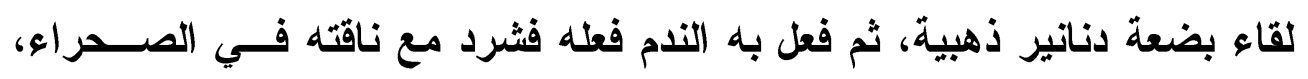

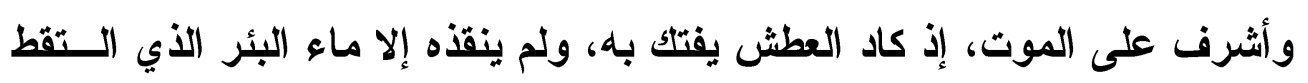

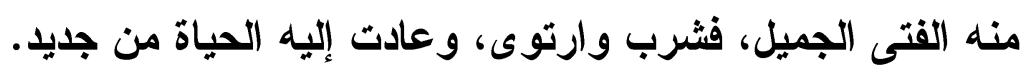

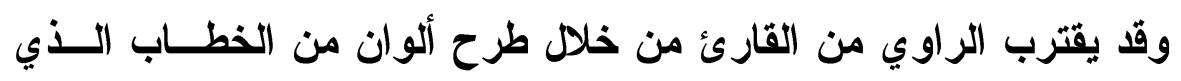

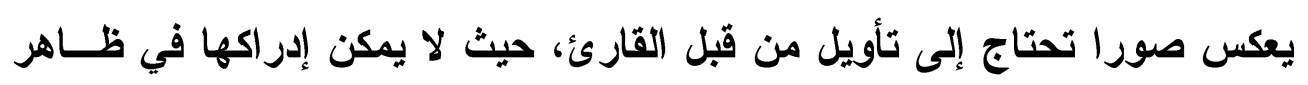

$$
\text { (Y) (1) الرواية ص } 979 \text { (1). }
$$


النص ويظهر ذلك في مقدمات بعض فصول الرواية ونهاياتهـا، وفــي بــايات

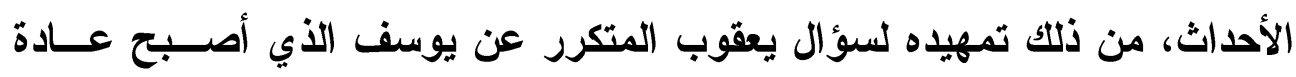

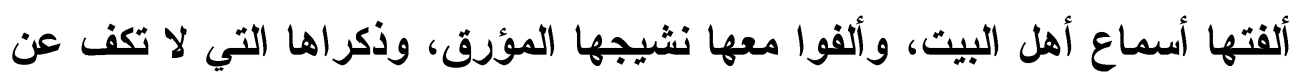

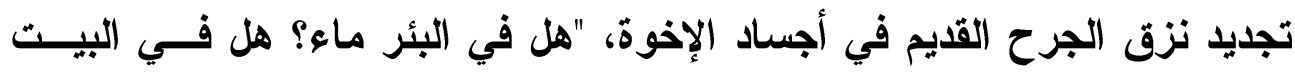

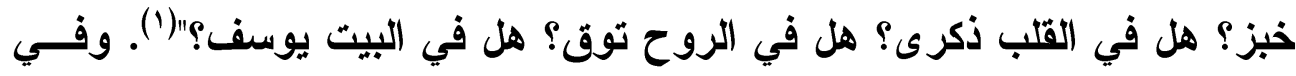

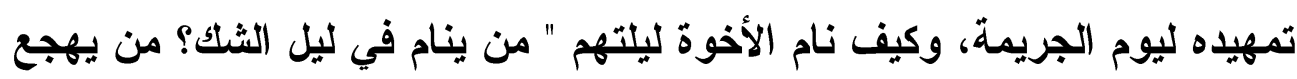

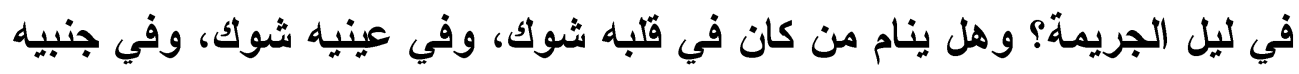

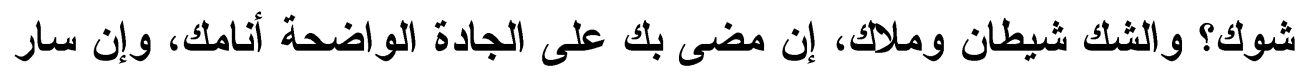

بك إلى الهاوية أيقظكك". (ץ)

أما أسلوب العرض ففيه يتلاشى صوت الراوي، ويعلو صوت الثخصيات

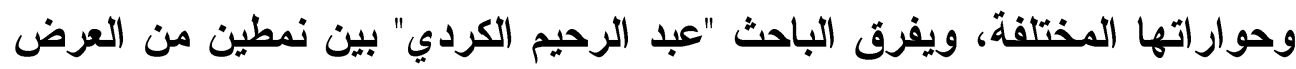

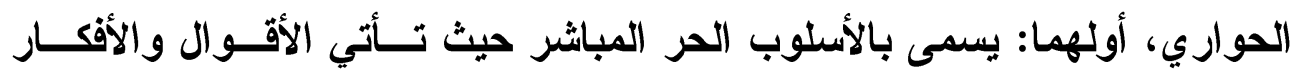

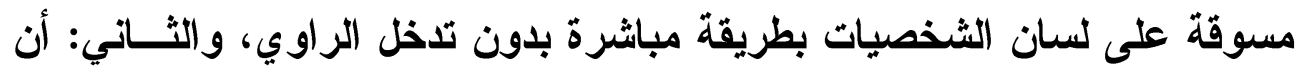

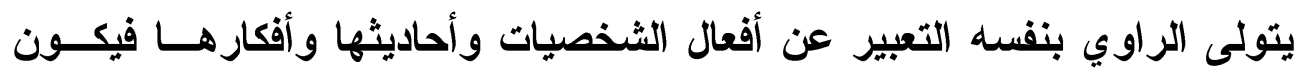

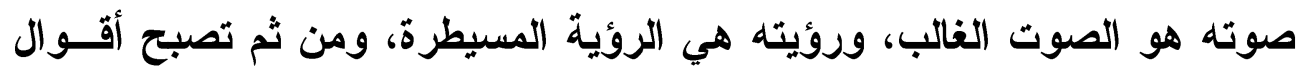

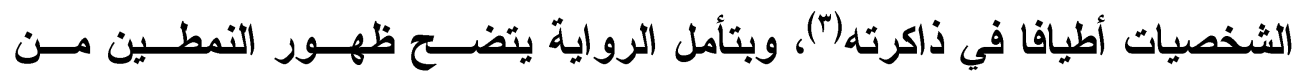
الحوار، فيظهر الأول في حوار نساء مصر حول يوسف تعقيبا على سجنه، فقالت

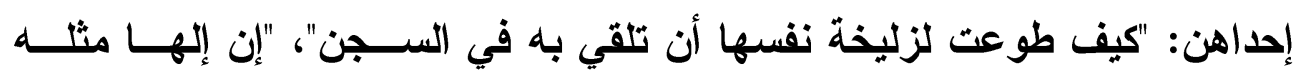

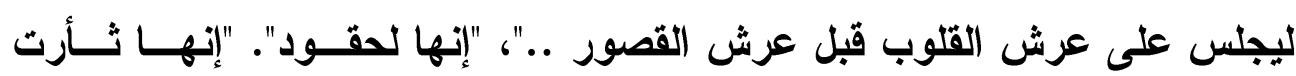

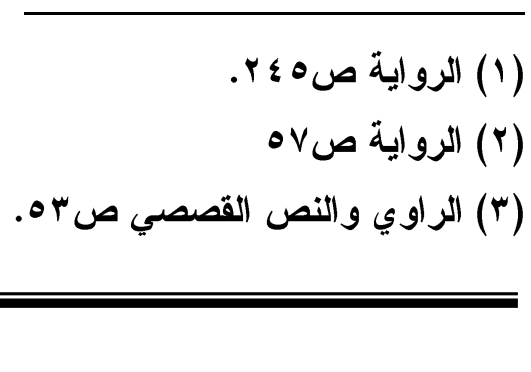




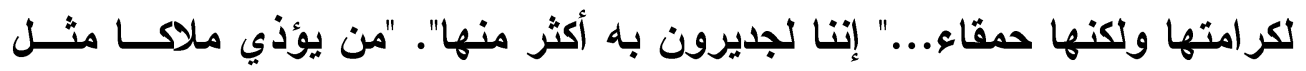
يوسف؟ ....". (1) وأما النوع الثاني الذي يظهر فيه الراوي متحكما في حوار الثخصـيات

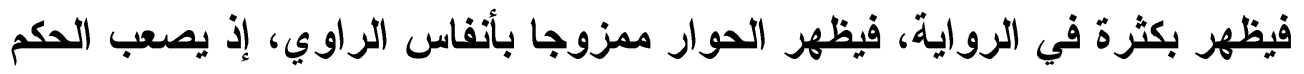

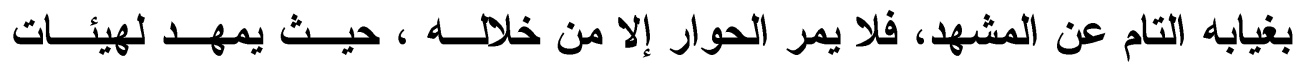

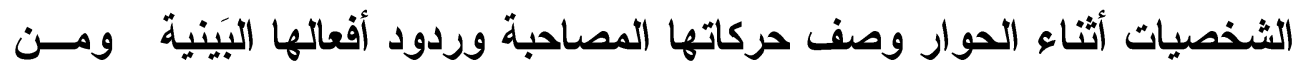

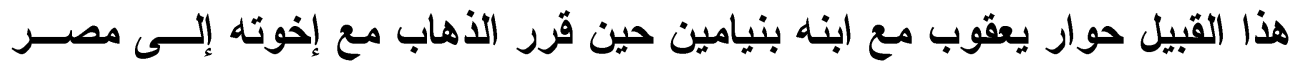

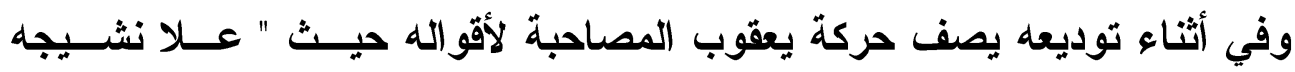
واحتضنه "بنيامين" وهدأ من رجفة جسده، "سنحاول أن نعود ســريعا ، ورجــاه

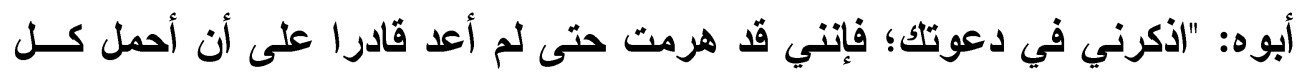

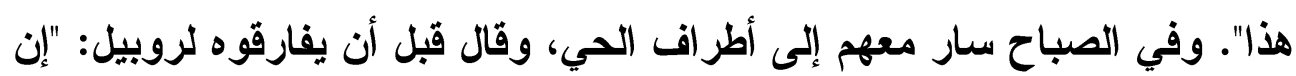

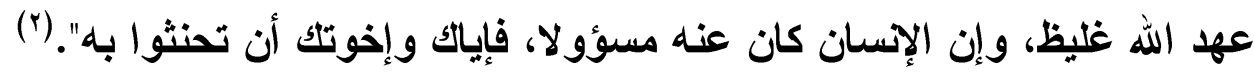

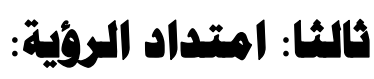
يقصد بامتداد الروئية تأمل الاختيارات المتاحة أمام الراوي فــي عـرض

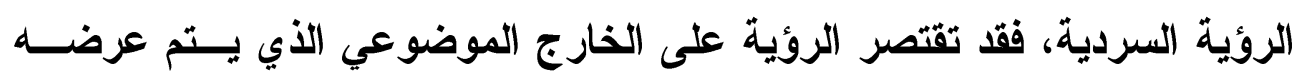

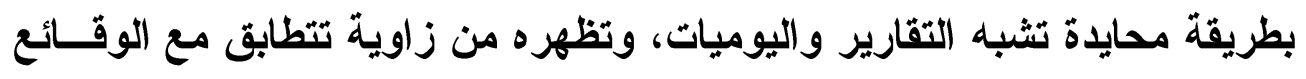

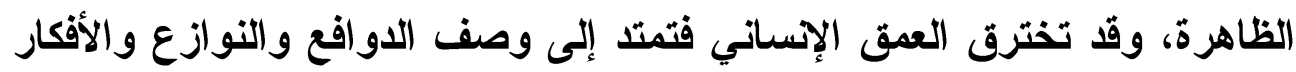

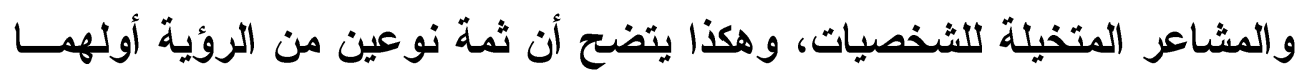
روئة خارجية، والثاني روئية داخلية.

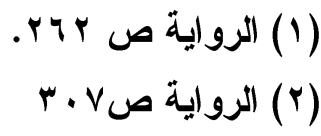




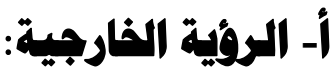

ترتبط الروئية الخارجية بصوت مجهول لا علاقة له بالثخصـيات والحسدث

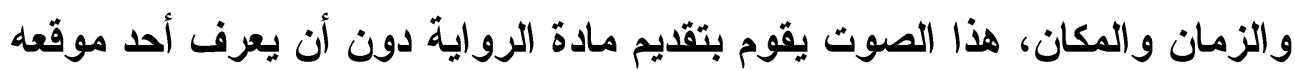

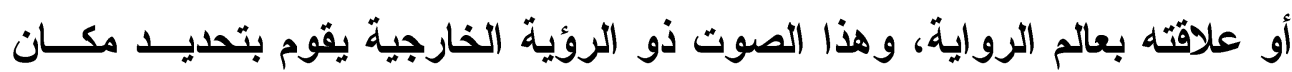

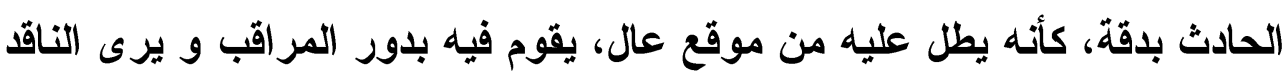

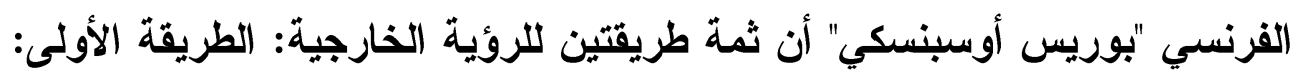

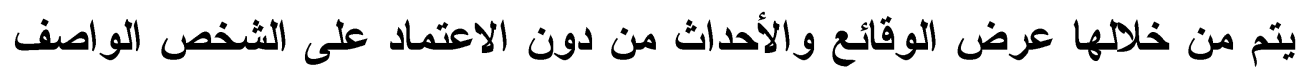

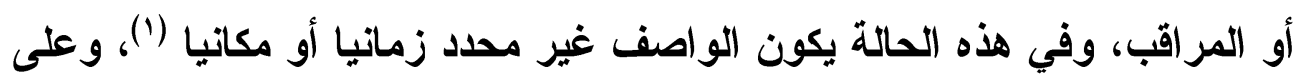

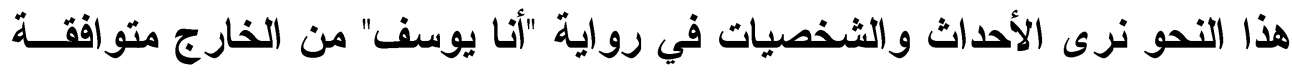
في ظهورها مع معطيات الخط التاريخي لها، فتظهر على النحو الآتي:

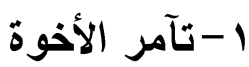

r- إلقاء يوسف في الجب. ب- التقاط القافلة له.

ع - إقامته في كنف عزيز مصر .

ه- احتيال امرأة العزيز ليوسف.

$$
\text { צ- السجن. }
$$

V

1- امتلالك يوسف خزائن مصر.

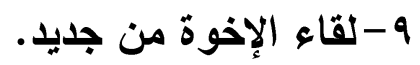

(1) شعرية التأليف، مرجع سابق ص997 
والطريقة الثانية للروئية الخارجية: تحيل إلـى رأي مراقـب، ســواء كــان مشاركا في الأحداث أو غير مشارك، حيث يتم وصف شخصيات من وجهة نظــــ شخصية أخرى وتوجد صور كثيرة تمثل هذه الطريقة في رواية "أنا يوسف" منها

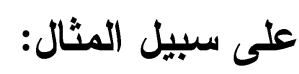
1- الأئب العسعاس يصف عالم البشر. r -الإخوة يصفون يوسف. r- الأئب الأطحل يصف الإخوة.

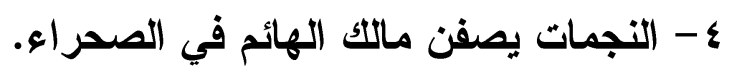
ه - عزيز مصر يصف زوجته زليخة. ه- نساء مصر يصفن امرأة العزيز. צ - زوجات الأبناء يصفن يعقوب حين عرف ريح يوسف.

\section{ب- اللوقية الداخلية:}

تسعى الروئية الاخلية إلى تقصي الحالة الاذاخلية التي تتضــمن الــوعي الأتي والثعوري للشخصيات والتي لا يمكن للمشاهد الوصول إليهـــا ظاهريـــا،

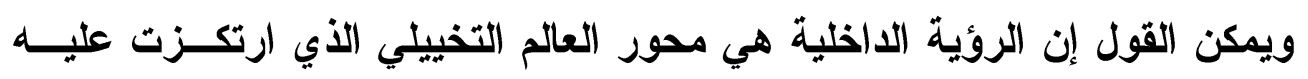
الرواية، فالر اوي قد جال في العوالم الاخلية المتخيلة لكل الشخصيات الفاعلة في الأحداث، وتعمق في نوازعها ودوافعها وشعورها، قبل وبعد وأثنـــاء الأحــداث، فوقف الر اوي طويلا عند مكر الإخوة، قسوة "يهوذا"، وندم "روبيل"، واسـترحام

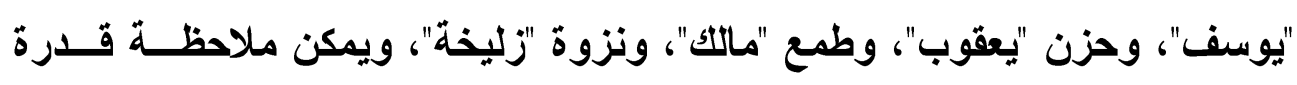
المؤلف على تجسيد هذا الثعور الأخلي من خلال ربطه بعالم الحس، فيمزج بين الحس والشعور، ومن ذلك وصفه حزن "روبيل" وبكائه على يوسف، وما فرط من في من

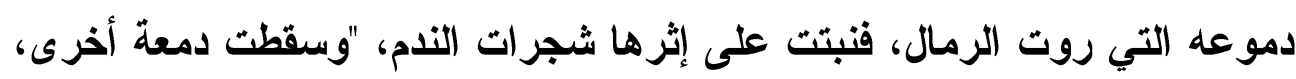


وغاصت في الرمل، وداسها هذه المرة حتى لا تنبت شجرة جديدة من الندم، لكنها

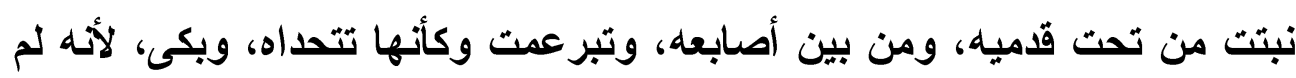

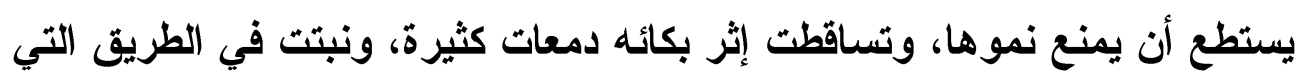
يمثيها إلى أخيها شجرات ندم كثيرة....". (1) ومن ذلك تصويره حسرة "مالكك" على تفريطه في يوسف بعـــ أن اتخـــه

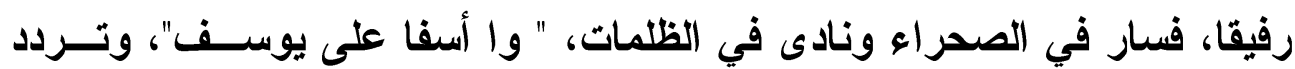

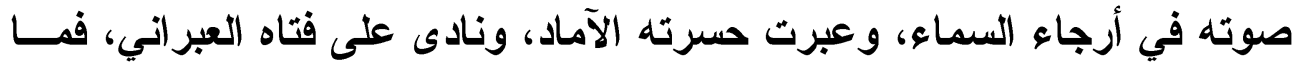

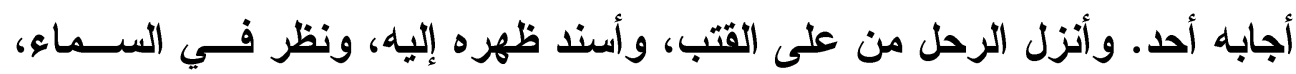

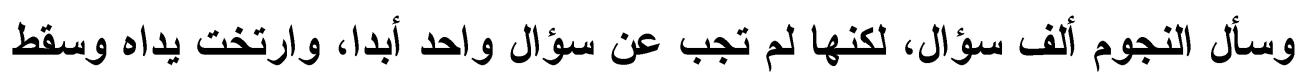

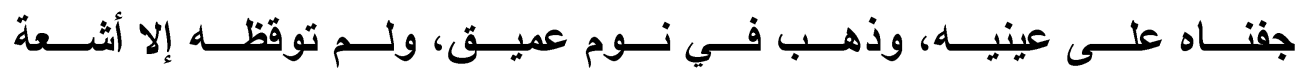

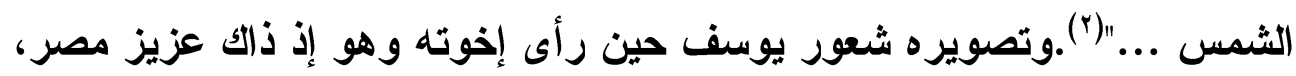

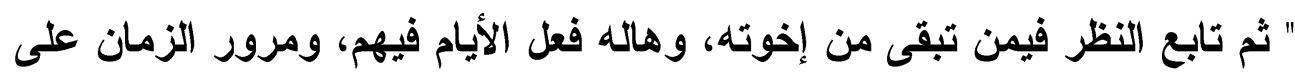

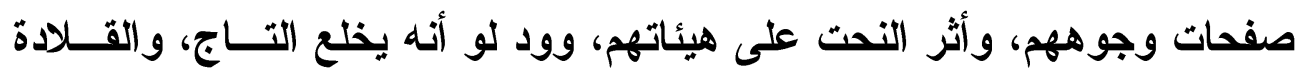

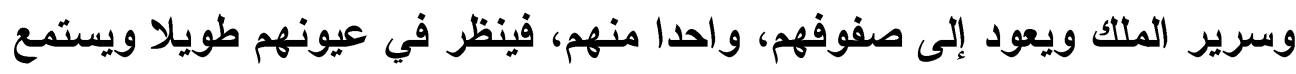

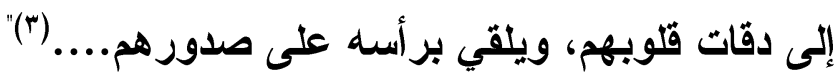

$$
\begin{aligned}
& \text { (1) (الرواية ص99 } 1 \text { (1) } \\
& \text { (r) الزواية ص الرواية صون } 174 \\
& \text { (r) الزواية ص99 بr. }
\end{aligned}
$$




\section{الفاتمة}

ا- لا خلاف أن قصة يوسف عليه السلام كانت ولا تــز ال أنموذجـــا للحكايــة الأثيرة عن الصراع الإنساني الأي تصطخب على مسرحه العديا من القوى والمتناقضات، ويتجلى على الطريق ما بينهما من قيم ونوازع إنسانية، ومما

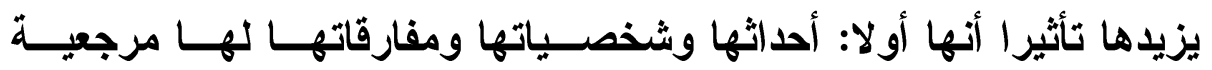

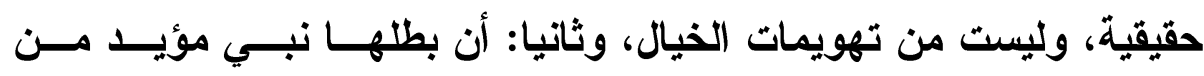
السماء، وما هو إلا واحد من أولئك الأين اختار لهم الباري أن يكونوا أسوة لإخوانهم من بني البشر، فقويت محتتهم، واحتدمت أمام أعيــنهم ظلامـــات الإنسان، تمحيصا واصطفاء، وهكذا فأنوار "تبوة" يوسف عليه الســلام لـــ تسطع من بين مطارف العز، في أبهاء القصور بل من دجنات الظــلام فـي غياهب السجن. r- إن الكاتب قرر أن يخوض اختبارا فنيا حين عمد إلى التاريخ ليتخـــ منـــهـ مادة جاهزة يقيم عليها صرحه الإبلاعي، ومن ثم فاختبار الكاتب لن يكـون في جديد المحتوى الأي سبقه إليه التاريخ، وإنما يكون على مستوى رؤيته لهذا المحتوى، وطريقة تقديمه بما يوضح الفارق بين سرد الراوي وتوثيقية

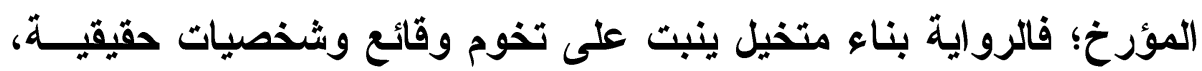
ومن ثم يتجه النظر إلى ما يضطلع به الراوي من الوسائل والحيل التي من شأنها أن تعيد الأحداث والشخصيات من جديد على مدرج الحياة، يسـائلها عن الاوافع والأسباب وعن أحوالها في العواقب والغايات. r- - الراوي في رواية أنا يوسف ينتمي لنوعية الراوي العليم الأي يطل علــى الأحداث من زاوية علوية ويصف الشخصيات بضمير الغائب. 


\section{الروية السردية في رواية أنا يوسف للكاتب أيمن العتوم}

ع- تحكم في تنوع زوايا الروئية عناصر عدة أولها الموقع الـــي يطـلـل منـــه

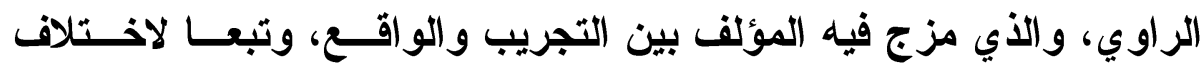

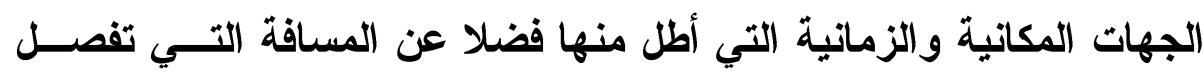
الراوي عن المؤلف و الثخصيات والقارئ.

ه- الروئة في رواية أنا يوسف تنوعت من حيث العمق إلى روئية اكتفى فيهــا

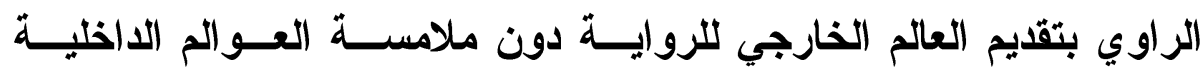

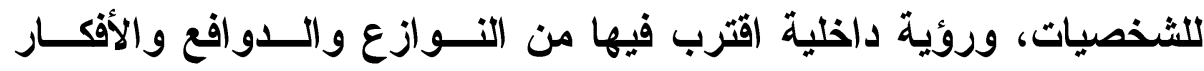
الا اخلية للشخصيات. 


\section{الروئة العردية في رواية أنا يوسف للكاتب أيمن العتوم}

\section{فهرس المرابجع}

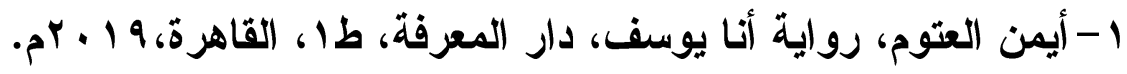
r-بوريس أوسبنسكي، شعرية التأليف، ت سعيد الغـانمي، المجلـس الأعلـى

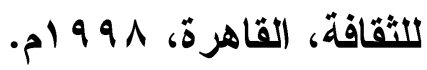
r-تزفتيان تودوروف، الشعرية.ت شكري المبخوت، طץ، دار توبقـال، الــدار البيضاء، المغرب • 99 ام. ع - جون هالبرين، نظرية الرواية، ت محيي الــدين صــبحي، منشــورات وزارة الثقافة، دمشث، ه-سعيد يقطين، تحليل الخطاب الروائي، المركز الثقافي العربي، طب، بيـروت،

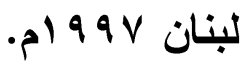
צ-سيزا قاسم بناء الرواية، مكتبة الأسرة، القاهرة، ع + . rم. V- عبد الرحيم الكردي، الراوي والـــص القصصــي، مكتبــة الآداب، القـــاهرة،

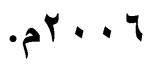
^-نانسي كريس تقنيات كتابة الرواية، ت زينة جابر إدريس الدار العربية للعلوم ناشرون ط البيروت، لبنان ، 9 ، . ب م. 9-يمنى العيد، تقنيات الســرد الروائسي فـي ضــوء المـنهج البنيـوي، دار القار ابي،ط'،بيزوت، لبنان، • 1 • r . 